\title{
Targeting folate receptor alpha for cancer treatment
}

Review

\author{
Anthony Cheung ${ }^{1,2, *}$, Heather J. Bax ${ }^{1,3, *}$, Debra H. Josephs ${ }^{1,3}$, Kristina M. Ilieva ${ }^{1,2}$, \\ Giulia Pellizzari ${ }^{1}$, James Opzoomer ${ }^{1}$, Jacinta Bloomfield ${ }^{1}$, Matthew Fittall ${ }^{1,2}$, Anita \\ Grigoriadis' ${ }^{2}$, Mariangela Figini ${ }^{4}$, Silvana Canevari ${ }^{4}$, James F. Spicer ${ }^{3}$, Andrew N. \\ Tutt $^{2}$ and Sophia N. Karagiannis ${ }^{1,2}$ \\ 1 St. John's Institute of Dermatology, Division of Genetics and Molecular Medicine, Faculty of Life Sciences and Medicine, \\ King's College London \& NIHR Biomedical Research Centre at Guy's and St. Thomas' Hospitals and King's College London, \\ Guy's Hospital, London, United Kingdom \\ ${ }^{2}$ Breast Cancer Now Research Unit, Faculty of Life Sciences and Medicine, Guy's Hospital, King's College London, London, \\ United Kingdom \\ ${ }^{3}$ Division of Cancer Studies, Faculty of Life Sciences and Medicine, Guy's Hospital, King's College London, London, United \\ Kingdom \\ ${ }^{4}$ Unit of Molecular Therapies, Department of Experimental Oncology and Molecular Medicine, Fondazione IRCCS Istituto \\ Nazionale dei Tumori, Milan, Italy \\ * These authors have contributed equally to this work \\ Correspondence to: Sophia N. Karagiannis, email: sophia.karagiannis@kcl.ac.uk
}

Keywords: folate receptor alpha, cancer, biomarker, monoclonal antibodies, immunotherapy

Received: March 25, 2016

Accepted: May 19, 2016

Published: May 27, 2016

\section{ABSTRACT}

Promising targeted treatments and immunotherapy strategies in oncology and advancements in our understanding of molecular pathways that underpin cancer development have reignited interest in the tumor-associated antigen Folate Receptor alpha (FRa). FRa is a glycosylphosphatidylinositol (GPI)-anchored membrane protein. Its overexpression in tumors such as ovarian, breast and lung cancers, low and restricted distribution in normal tissues, alongside emerging insights into tumorpromoting functions and association of expression with patient prognosis, together render FRa an attractive therapeutic target. In this review, we summarize the role of $F R a$ in cancer development, we consider FRa as a potential diagnostic and prognostic tool, and we discuss different targeted treatment approaches with a specific focus on monoclonal antibodies. Renewed attention to FRa may point to novel individualized treatment approaches to improve the clinical management of patient groups that do not adequately benefit from current conventional therapies.

\section{INTRODUCTION}

Water soluble vitamin B9 can occur as 'folate' (enriched in dark leafy vegetables) and as 'folic acid' (a synthetic folate compound used as a vitamin supplement). A sufficient intake of folate is needed in rapidly proliferating cells for the one-carbon metabolic reaction and DNA biosynthesis, repair and methylation [1]. Dysregulated folate metabolism has been associated with embryonic developmental disorders, cardiovascular disease and brain defects [2-4]. Folate is transported across the cellular membrane in three ways. The main route of uptake is through the reduced folate carrier (RFC), which is ubiquitously distributed and aids the uptake of dietary folate [5]. The second route is through the proton- coupled folate transporter (PCFT), which utilizes the transmembrane proton gradient to mediate folate transport into the cells [6]. Finally, folate can be transported by folate receptors, of which there are four glycopolypeptide members (FR $\alpha, F R \beta, F R \gamma$ and FR $\delta$ ), with molecular weights ranging from 38 to $45 \mathrm{kDa}$ [7]. The alpha isoform, Folate Receptor $\alpha(\mathrm{FR} \alpha)$, also known as FOLR1 or folate binding protein (FBP), is a glycosylphosphatidylinositol (GPI)-anchored membrane protein with high affinity for binding and coordinating transport of the active form of folate, 5-methyltetrahydrofolate (5-MTF) [8, 9].

$\mathrm{FR} \alpha$ has been reported to be overexpressed in solid tumors such as ovarian, lung and breast carcinomas [1012]. On the other hand, the distribution of $F R \alpha$ in normal human tissues is restricted to low level expression in the 
apical surfaces of some organs such as the kidney, lung and choroid plexus [9]. Studies have demonstrated that overexpression of FR $\alpha$ may render a growth advantage for cancer cells through mechanisms both relating to, as well as being independent of, folate uptake $[13,14]$.

Here, we review FR $\alpha$ as a folate carrier and a tumorassociated signalling molecule in relation to its potential as a target, and as a diagnostic and prognostic tool, in oncology. We describe examples of past and present treatment approaches and promising therapeutic avenues, with specific focus on monoclonal antibodies for ovarian, lung and breast cancer, as examples of FR $\alpha$-positive malignancies.

\section{FR $\alpha$-MEDIATED INTERNALIZATION OF FOLATES AND REGULATION OF CANCER SIGNALING}

Traditionally FR $\alpha$ is described as a transporter to internalize folate. Folate trafficking via FR $\alpha$ is thought to occur by a non-classical lipid raft-mediated endocytosis pathway, namely potocytosis, which does not involve clathrin-coated pits. This pathway is associated with caveolae vesicles [15]. Folate binds specifically to FR $\alpha$ creating a receptor-ligand complex; then through invagination and budding off, intracellular vesicles are formed. Once internalized, the vesicles uncoat and single vesicles join together forming early endosomes, which undergo acidification and subsequent fusion with lysosomes to release folates for the one-carbon metabolic reaction $[16,17]$.

$\mathrm{FR} \alpha$ overexpression in different solid tumors can potentially contribute to cancer development in different ways. A number of studies have suggested parallel roles of FR $\alpha$ in both cell growth regulation and signaling functions. Boshnjaku et al. reported that following folate uptake and internalization, FR $\alpha$ can then translocate to the nucleus and act as a transcription factor, binding to cis-regulatory elements. Through this mechanism, FR $\alpha$ may directly regulate the expression of key developmental genes in cancer cells [18]. Ovarian cancer cells transfected with a single-chain intrabody targeting FR $\alpha$ showed reduced cell surface expression and subsequent impaired tumor cell proliferation, reduced colony formation, and dysregulated adhesion; together signs of reversing tumor cell transformed phenotype [19]. Furthermore, folate uptake can promote cancer cell proliferation, migration and loss of adhesion through downregulation of the cell-cell adhesion molecule, E-cadherin, promoting cellular motility and metastasis. In concordance, it was also reported that the absence of E-cadherin expression correlated with decreased patient survival in ovarian carcinomas [20]. FR $\alpha$ knockdown in ovarian carcinoma cell lines could inhibit folate-mediated cell proliferation and suppress an invasive phenotype [14]. FR $\alpha$ has also been demonstrated to inhibit caveolin-1, thereby supporting anchorage- independent growth and proliferation of tumor cells and promoting cancer progression $[21,22]$.

More recently, FR $\alpha$ has been demonstrated to contribute to cancer malignancy by acting as a signaling molecule. Similarly to other GPI family proteins, FR $\alpha$ is thought to initiate intracellular regulatory signaling networks upon binding with folate. FR $\alpha$ overexpression has been reported to be associated with increased STAT3 signaling [23]. Hansen et al. demonstrated that folate binding to FR $\alpha$ could induce STAT3 activation via a GP130 co-receptor-mediated JAK-dependent process [24]. Moreover, phosphorylated LYN tyrosine kinase was found in anti-FR $\mathrm{mAb}$ precipitates of FR $\alpha$-expressing tumor cell lysates [25]. These findings suggest the receptor has the potential to form macromolecular complexes in which FR $\alpha$ can trigger intracellular signaling. The basal subtype of breast cancers have been observed to express high levels of LYN, which has been reported to regulate the phosphorylation of a non-receptor tyrosine kinase, PEAK1, to promote ERK and STAT3 activation, as well as to support cellular transition to a mesenchymal phenotype, increasing cell motility and invasion [26]. Furthermore, FR $\alpha$ overexpression is frequently reported to be expressed in metastatic foci and recurrent tumors [27], even in microenvironments with limited folate availability.

Together, these studies strongly suggest that FR $\alpha$ may function not only as a folate transporter, but may also confer signaling and growth advantages on malignant cells (as depicted in Figure 1) [28].

\section{FR $\alpha$ : A THERAPEUTIC TARGET, DIAGNOSTIC AND/OR PROGNOSTIC TOOL FOR THE MANAGEMENT OF SOLID TUMORS}

\section{FR $\alpha$ expression in non-malignant tissues}

FR $\alpha$ expression has been examined by several methods including immunohistochemistry using monoclonal antibodies, folate ligand binding assays, measurement of mRNA levels by qPCR, and by flow cytometry [8, 29-31]. Expression of FR $\alpha$ in normal tissues is restricted to the luminal surface of the kidney, intestine, lung, retina, placenta and choroid plexus [30, 32, 33]. Importantly, in all normal tissues except the kidneys, the receptor is confined to the apical surface of the epithelium that is out of direct contact with folate and any folate receptor-targeting agents in the circulation $[34,35]$. The FR $\alpha$ expressed in the kidneys functions as a salvage receptor to retrieve and prevent loss of folate in the urine. However, folate is not retained in the kidneys, and as such no lethal toxicities have been observed in rodent or human subjects treated with FR $\alpha$-targeting agents $[35,36]$. 


\section{FR $\alpha$ expression in epithelial tumors}

Cancers found to overexpress FR $\alpha$ are often of epithelial origin, including cancers of the ovary, breast, pleura, lung, cervix, endometrium, kidney, bladder and brain [29, 37]. FOLR1 mRNA expression levels for various types of cancer have been studied (expression levels in cell line panels summarized in Figure 2) [38].

\section{Ovarian cancer}

In ovarian cancer, FR $\alpha$ is overexpressed in $80 \%$ of epithelial ovarian cancers (EOCs) and expression has been shown to significantly correlate with histological grade and stage $[10,14]$. The expression of FR $\alpha$ is considered a marker of tumor aggressiveness, and although there is conflicting data when all ovarian carcinoma histotypes are considered, elevated FR $\alpha$ expression is associated with lower disease-free interval (DFI) and poor overall survival (OS) in patients with disease of serous origin [27, 39].

FR $\alpha$ is also thought to facilitate resistance to chemotherapy in ovarian carcinoma patients, with higher tissue FR $\alpha$ expression associated with lower response rate to chemotherapeutic agents $[28,39,40]$. Nevertheless, a number of studies have shown that FR $\alpha$ tumor surface expression does not differ between paired samples before and after chemotherapy. This suggests that chemotherapeutic agents do not affect antigen expression and FR $\alpha$-positivity can be used to detect recurrent disease $[41,42]$ and strengthen the rationale for the potential utility of FR $\alpha$-targeting therapeutics for both newly diagnosed and recurrent disease.

\section{Lung cancer}

Non-small cell lung cancer (NSCLC) accounts for $80 \%$ of lung cancers. Despite advances in surgical techniques, radiotherapeutic approaches and chemotherapy regimens, and the development of novel molecular targeted agents, the prognosis is poor with a 5 -year all-stage survival rate of $21 \%$ [11]. Both common subtypes of NSCLC, adenocarcinoma and squamous cell carcinomas (SCCs), to a lesser degree, have been reported to express high levels of FR $\alpha$ [43-46]. The level of FR $\alpha$

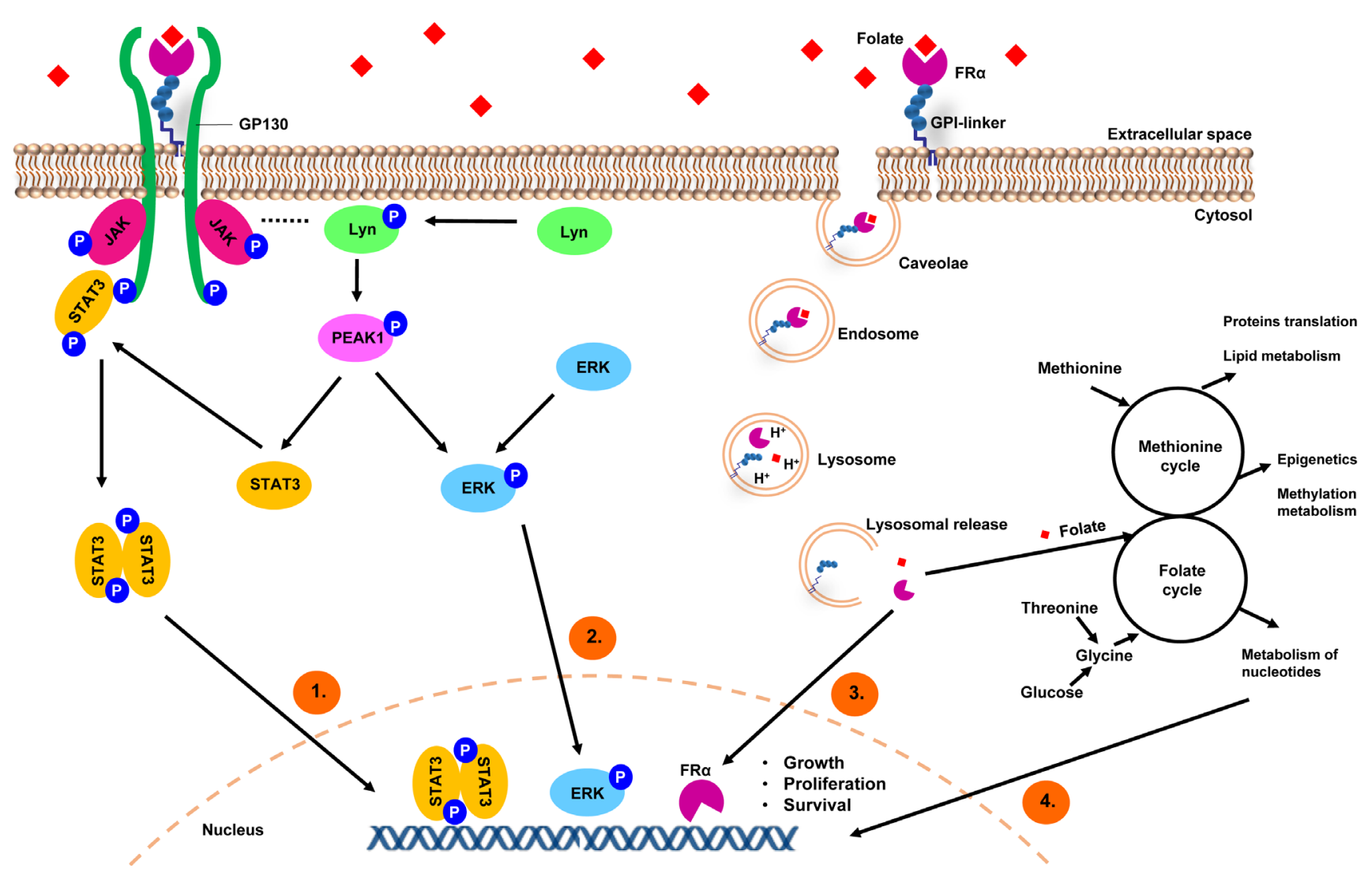

Figure 1: A model depicting FR $\alpha$-mediated internalization of folates and regulation of cancer signaling. 1) Folate binding to FR $\alpha$ could induce STAT3 activation via a GP130 co-receptor mediated JAK-dependent process. 2) FR $\alpha$ may form macromolecular complexes with LYN tyrosine kinase, which has been reported to regulate the phosphorylation of PEAK1 to promote ERK and STAT3 activation. 3) GPI-anchored FR $\alpha$ is internalized in caveolae vesicles and forms early endosomes, which undergo acidification and subsequent fusion with lysosomes to release FR $\alpha$ and folate. FR $\alpha$ is then translocated to the nucleus and acts directly as a transcription factor. 4) FR $\alpha$ acts as a folate transporter; a sufficient intake of folate is needed in rapidly proliferating cells for the one-carbon metabolic reaction and DNA biosynthesis, repair and methylation. 
expression by tumor cells was shown to be associated with improved OS in patients with resected adenocarcinomas [46]. Similarly, in another study, higher $\operatorname{FR} \alpha$ expression levels were observed in well-differentiated, earlier stage lung tumors compared to more poorly-differentiated tumors from advanced stage adenocarcinoma patients, and higher FOLR1 gene expression levels correlated with significantly higher 3-year disease free survival (DFS) and OS rates in this cohort as well [44]. Most recently, the validity of FR $\alpha$-targeting therapies, has been strengthened by observed concordance of high FR $\alpha$ levels between biopsies, primary tumors and metastases in these patients [11].

Overexpression of $\mathrm{FR} \alpha$ has also been detected in up to $72 \%$ of patients with another uncommon and aggressive form of thoracic cancer, pleural mesothelioma $[47,48]$. However, more studies are required to evaluate the diagnostic and prognostic significance of tumor FR $\alpha$ expression in mesothelioma.

\section{Breast cancer}

A number of studies have reported overexpression of FR $\alpha$ in breast cancers [12, 49]. Most recently, high FR $\alpha$ tissue expression was observed in $74 \%$ of estrogen receptor (ER)/progesterone receptor (PR)-negative breast cancers [13, 50-52]. Steroid hormones mediate physiologically normal $\mathrm{FR} \alpha$ regulation; in particular, oestrogen has been found to downregulate the expression of FR $\alpha$. This has been demonstrated in studies that report a negative correlation between tumors that express ER and those which express FR $\alpha[13,52]$. Supporting this notion, drugs such as tamoxifen, which bind and inhibit ER function, can also cause a rise in FR $\alpha$ expression [53]. Triple negative breast cancer (TNBC), which is characterized by the lack of ER, PR and human epidermal growth factor receptor 2 (HER2), represent $10-15 \%$ of all breast carcinomas. Despite representing a minority of breast cancer cases, this particular subtype accounts for a disproportionate number of cases of metastatic disease and deaths, due to its more aggressive natural history and lack of available targeted therapies [54, 55]. High FR $\alpha$ tissue expression was observed in $80 \%$ of TNBCs, making it an attractive therapeutic target in this breast cancer type [51].

FR $\alpha$ expression by breast carcinomas, including TNBCs, is significantly associated with high histologic grade and advanced stage, and high proliferative activity as determined by expression of Ki-67. Overexpression of FR $\alpha$ was also significantly associated with poorer disease-free survival $[49,52]$. In addition, correlation of high FR $\alpha$ expression between primary tumors and local and distant metastases has been observed, suggesting that most metastatic disease could potentially be treated with anti-FR $\alpha$ therapies when the primary tumor shows overexpression.

Overall, these studies, across a number of cancer cell types, suggest that targeting this tumor-associated antigen may offer clinical benefit to patients with unmet need for novel therapeutic options. The low and restricted

\section{FOLR1 - Entrez ID: 2348}

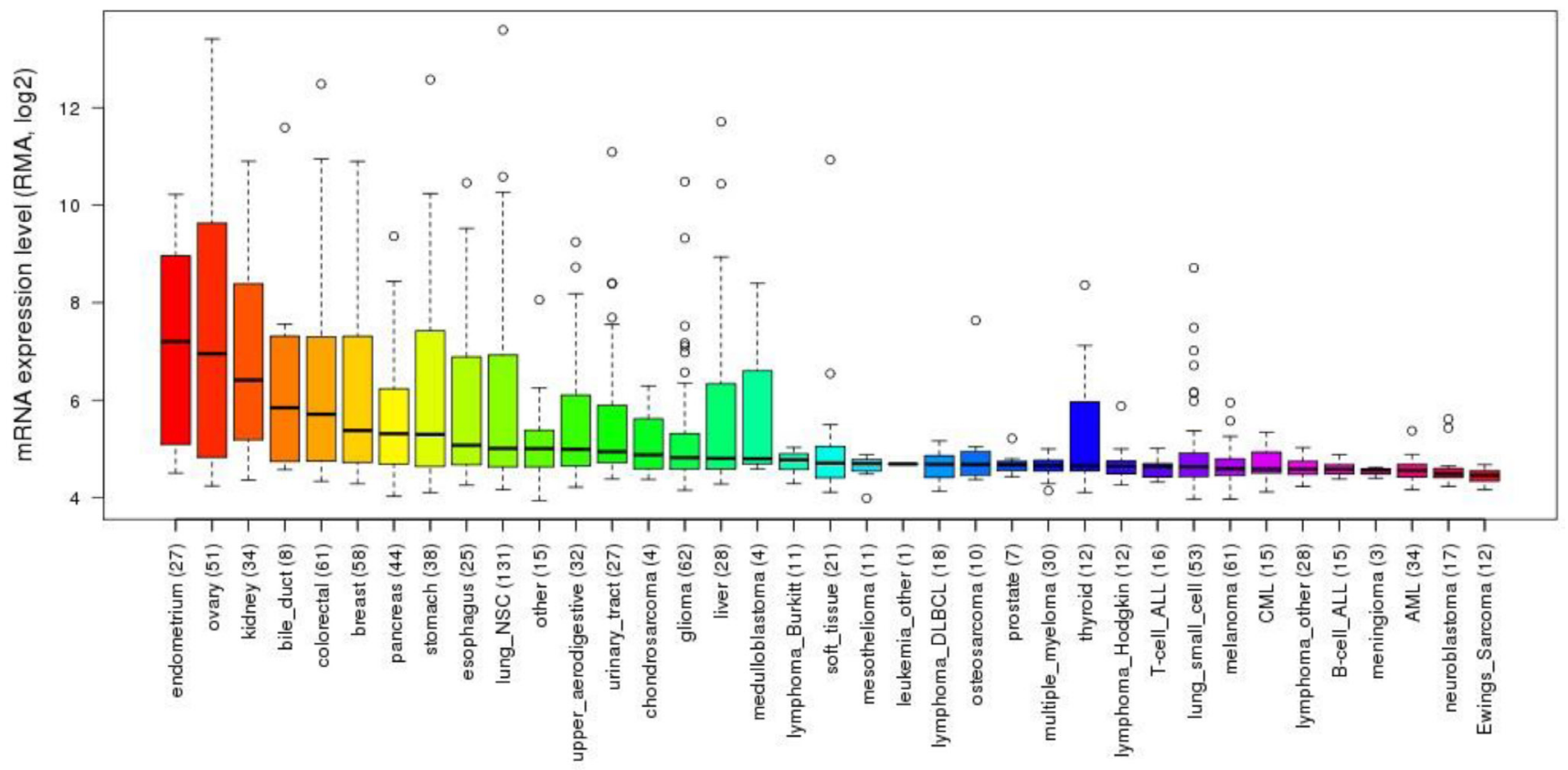

Figure 2: FOLR1 gene expression levels in cancer models. A summary of gene expression data (generated from the Cancer Cell Line Encyclopaedia) showing the levels of mRNA expression for the FOLR1 gene on a logarithmic scale in various cancer cell types. (parentheses show number of cell lines per tumor type) 
Table 1: Key clinical trials of FR $\alpha$-drug conjugate therapeutics.

\begin{tabular}{|c|c|c|c|c|c|c|c|}
\hline $\begin{array}{l}\text { Drug } \\
\text { Name }\end{array}$ & Alternative Name(s) & \begin{tabular}{|l|} 
Tumor \\
Type
\end{tabular} & Trial Design & Efficacy Outcome & Safety Outcome & \begin{tabular}{|l|} 
Imaging \\
Outcome \\
\end{tabular} & \begin{tabular}{|l|} 
Reference/ \\
Trial Number \\
\end{tabular} \\
\hline \multirow{3}{*}{ Vintafolide } & \multirow{3}{*}{$\begin{array}{l}\text { (i) EC145 } \\
\text { (ii) Folate-conjugated } \\
\text { DAVLBH }\end{array}$} & $\begin{array}{l}\text { Platinum- } \\
\text { resistant } \\
\text { ovarian } \\
\text { cancer }\end{array}$ & 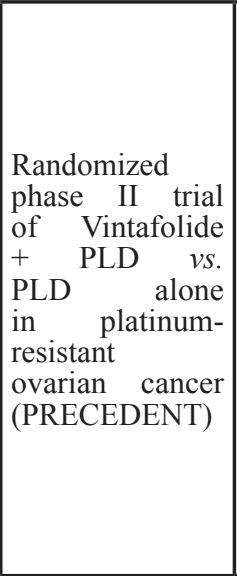 & \begin{tabular}{|l} 
Vintafolide \\
demonstrated \\
significantly \\
improved clinical \\
activity compared \\
with PLD alone. \\
Median PFS was \\
5.0 and 2.7 months \\
for vintafolide + \\
PLD and PLD-alone \\
arms, respectively $(P$ \\
$=0.031)$. Greatest \\
benefit observed in \\
patients with 100\% \\
FR+ lesions, with \\
median PFS 5.5 vs. \\
1.5 months for PLD \\
alone (P=0.013)
\end{tabular} & $\begin{array}{l}\text { Vintafolide } \\
+ \text { PLD was } \\
\text { well tolerated. } \\
\text { Frequency of } \\
\text { leukopenia, } \\
\text { neutropenia, } \\
\text { abdominal pain, } \\
\text { and peripheral } \\
\text { sensory } \\
\text { neuropathy } \\
\text { was higher in } \\
\text { vintafolide + } \\
\text { PLD vs. PLD } \\
\text { arm }\end{array}$ & N/A & $\begin{array}{l}{[77]} \\
\text { NCT00722592 }\end{array}$ \\
\hline & & $\begin{array}{l}\text { FR+ } \\
\text { platinum- } \\
\text { resistant } \\
\text { ovarian } \\
\text { cancer }\end{array}$ & $\begin{array}{l}\text { Phase III study } \\
\text { of vintafolide } \\
+\quad \text { PLD vs. } \\
\text { PLD alone in } \\
\text { patients with } \\
\text { FR+ platinum- } \\
\text { resistant } \\
\text { ovarian cancer } \\
\text { (PROCEED). }\end{array}$ & $\begin{array}{l}\text { At a prespecified } \\
\text { interim data analysis, } \\
\text { cessation of the study } \\
\text { was recommended } \\
\text { because vintafolide } \\
+ \text { PLD vs. PLD alone } \\
\text { did not meet the } \\
\text { prespecified criteria } \\
\text { for PFS }\end{array}$ & $\begin{array}{lr}\text { No } & \text { safety } \\
\text { concerns } & \text { were } \\
\text { detailed } & \end{array}$ & N/A & {$\left[\begin{array}{l}{[28]} \\
\text { NCT01170650 }\end{array}\right.$} \\
\hline & & $\begin{array}{l}\text { FR+ } \\
\text { NSCLC }\end{array}$ & \begin{tabular}{|l|} 
Randomized, \\
open-label, \\
phase II trial \\
of vintafolide \\
as second-line \\
treatment r vs. \\
vintafolide r \\
docetaxel $v s$. \\
docetaxel alone \\
in patients with \\
FR+ NSCLC \\
FARGET)
\end{tabular} & $\begin{array}{l}\text { Preliminary data } \\
\text { for vintafolide }+ \\
\text { docetaxel showed } \\
\text { improvement } \\
\text { across all efficacy } \\
\text { endpoints rs. } \\
\text { docetaxel alone. The } \\
\text { best improvement } \\
\text { was observed in } \\
\text { the predefined } \\
\text { adenocarcinoma } \\
\text { patient subgroup }\end{array}$ & $\begin{array}{l}\text { The safety profile } \\
\text { was manageable } \\
\text { and consistent } \\
\text { with the AEs } \\
\text { observed with } \\
\text { both therapies }\end{array}$ & N/A & $\begin{array}{l}{[75,76]} \\
\text { NCT01577654 }\end{array}$ \\
\hline $\mathrm{EC} 0225$ & $\begin{array}{l}\text { (i) Folate- } \\
\text { desacetylvinblastine- } \\
\text { hydrazide } \\
\text { (ii) folate-mitomycin } \\
\text { C }\end{array}$ & $\begin{array}{l}\text { Solid } \\
\text { tumors }\end{array}$ & $\begin{array}{lr}\text { Phase I } & \text { study } \\
\text { of EC0225 in } \\
\text { patients r with } \\
\text { solid r tumors } \\
\text { (refractory r } & \text { or } \\
\text { metastatic) } & \end{array}$ & $\begin{array}{l}\text { Disease stabilization } \\
(\geq 4 \text { months }) \text { was } \\
\text { observed in 26/63 } \\
\text { patients }\end{array}$ & $\begin{array}{l}\text { EC0225 was } \\
\text { well -tolerated } \\
\text { at doses } \leq 2.3 \\
\text { mg/m². Most } \\
\text { frequent AEs } \\
\text { included anemia, } \\
\text { constipation, } \\
\text { leukopenia, } \\
\text { fatigue. G3 } \\
\text { hypotension and } \\
\text { G4 neutropenia } \\
\text { occurred in } 1 \\
\text { patient each at } \\
\text { the highest dose } \\
\text { tested (2.88mg/ } \\
\left.m^{2}\right) \text { defining the } \\
\text { MTD }\end{array}$ & N/A & $\begin{array}{l}{[79]} \\
\text { NCT00441870 }\end{array}$ \\
\hline
\end{tabular}




\begin{tabular}{|c|c|c|c|c|c|c|c|}
\hline Epofolate & $\begin{array}{l}\text { (i) BMS- } 753493 \\
\text { (ii) Folate-conjugated } \\
\text { epothilone A }\end{array}$ & $\begin{array}{l}\text { Solid } \\
\text { tumors }\end{array}$ & $\begin{array}{l}\text { Phase I study of } \\
\text { epothilone folate } \\
\text { (BMS-753493) } \\
\text { in patients with } \\
\text { advanced solid } \\
\text { tumors }\end{array}$ & $\begin{array}{l}\text { Best overall response } \\
\text { was SD in 19\% } \\
\text { patients. Median } \\
\text { duration of response } \\
\text { was } 85 \text { days. No } \\
\text { correlation between } \\
\text { FR status and } \\
\text { response. Interim } \\
\text { analysis indicated } \\
\text { that the benefit risk } \\
\text { profile of BMS- } \\
753493 \text { was not } \\
\text { favorable and did } \\
\text { not support further } \\
\text { investigation of this } \\
\text { agent }\end{array}$ & $\begin{array}{l}\text { The MTD } \\
\text { was reached. } \\
\text { DLTs included } \\
\text { ALT and AST } \\
\text { elevations, } \\
\text { diarrhoea, } \\
\text { nausea, fatigue, } \\
\text { oesophagitis } \\
\text { and mucosal } \\
\text { inflammation }\end{array}$ & N/A & $\begin{array}{l}{[80,81]} \\
\text { NCT00546247 }\end{array}$ \\
\hline EC0489 & $\begin{array}{l}\text { Folate- } \\
\text { desacetylvinblastine } \\
\text { hydrazide with } \\
\text { modified linker }\end{array}$ & $\begin{array}{l}\text { Solid } \\
\text { tumors }\end{array}$ & $\begin{array}{lr}\text { Phase I } & \text { study } \\
\text { of EC0489 in } \\
\text { patients } & \text { with } \\
\text { refractory } & \text { or } \\
\text { metastatic } & \\
\text { tumors } & \end{array}$ & Not reported & $\begin{array}{l}\text { Patients treated } \\
\text { at } 2.5 \mathrm{mg} / \mathrm{m}^{2} \\
\text { experienced } \\
\text { toxicities } \\
\text { characteristic of } \\
\text { vinca alkaloids } \\
\text { (e.g., mild } \\
\text { neuropathy), but } \\
\text { not significant } \\
\text { constipation nor } \\
\text { gastrointestinal- } \\
\text { related toxicity }\end{array}$ & N/A & $\begin{array}{l}{[82]} \\
\text { NCT00852189 }\end{array}$ \\
\hline EC1456 & Folate-tubulysin & $\begin{array}{l}\text { TNBC, } \\
\text { advanced } \\
\text { NSCLC } \\
\text { and } \\
\text { ovarian } \\
\text { cancer }\end{array}$ & $\begin{array}{l}\text { Phase I dose- } \\
\text { escalation study } \\
\text { of EC1456 (Part } \\
\text { A) including a } \\
\text { study of efficacy } \\
\text { in patients with } \\
\text { TNBC, advanced } \\
\text { NSCLC and } \\
\text { ovarian cancer } \\
\text { treated at the } \\
\text { MTD (Part B) }\end{array}$ & Data awaited & Data awaited & N/A & NCT01999738 \\
\hline
\end{tabular}

AE, adverse event; ALT, alanine aminotransferase; AST, aspartate aminotransferase; DLT, dose-limiting toxicity; G, CTCAE grade; MTD, maximum tolerated dose; NSCLC, non-small cell lung cancer; PFS, progression-free survival; PLD, pegylated liposomal doxorubicin; SD, stable disease; TNBC, triple negative breast cancer. Clinical trial number (NCT) available from: http://clinicaltrials.gov.

distribution of FR $\alpha$ in normal tissues, alongside the presence of other folate transporters, which can process folates, may suggest that targeting FR $\alpha$ would not restrict all folate uptake, and may not affect normal cell survival or proliferation nor impair normal tissue homeostasis. Overexpression of FR $\alpha$ in the blood-accessible basal and lateral membranes of epithelial carcinomas, and suggested contributions to tumor cell growth and proliferation, together point to targeting $\mathrm{FR} \alpha$ as an attractive and potentially non-toxic treatment approach.

\section{Soluble FRa}

Membrane-associated FR $\alpha$ can also be released by proteolytic cleavage with membrane-associated protease and GPI-specific phospholipases $[9,56]$. FR $\alpha$ is detected as a soluble form in the sera of some cancer patients by a number of techniques, including microfiltration, immunoblotting, electrochemiluminescence, and ELISA
$[23,57-59]$. Soluble FR $\alpha(\operatorname{sFR} \alpha)$ is reported to be low or undetected in normal human sera $[23,58]$. A number of studies of the serum from patients with both serous and non-serous ovarian carcinomas have demonstrated elevated levels of $\mathrm{sFR} \alpha$, compared to healthy individuals. Importantly for the potential use of $\operatorname{sFR} \alpha$ as a diagnostic biomarker, elevated levels of $\mathrm{sFR} \alpha$ were observed even in early stage I/II disease [23, 59]. Furthermore, levels of $\mathrm{sFR} \alpha$ have been reported to correlate with FIGO stage, histological types and tumor grade [57, 59]. Most recently, in a cohort of 221 patients, the prognostic significance of sFR $\alpha$ was supported by findings that patients with lower $\mathrm{sFR} \alpha$ levels had significantly longer progression-free survival (PFS) than those with high serum levels. A trend in increasing sFR $\alpha$ and tumor expression levels measured by immunohistochemistry was also reported, suggesting that $\operatorname{sFR} \alpha$ may offer a minimally-invasive alternative to predict local tumor FR $\alpha$ positivity and may present a surrogate marker for FR $\alpha$ tumor expression [57].

Studies are still needed to examine sFR $\alpha$ levels in 
the serum of patients with breast and lung cancers in order to evaluate its potential as a diagnostic and prognostic biomarker across cancer types and in those individuals where other clinically-used serum biomarkers are absent or unhelpful in monitoring or predicting disease progression. In addition, studies are required to evaluate the potential inhibitory impact of high sFR $\alpha$ levels on the efficacy of FR $\alpha$-targeting therapies.

\section{CLINICAL APPLICATION OF FR $\alpha-$ BASED AGENTS}

A range of $\mathrm{FR} \alpha$-targeting approaches, including folic acid derivatives, folate drug-conjugates and small molecules, vaccines, T-cell therapies and monoclonal antibodies, have been developed for clinical application for both imaging and therapeutic purposes (summarized in Figure 3).

\section{FR $\alpha$-targeted imaging}

Although there is evidence to suggest that FR $\alpha$ positive tumors can be detected by radiolabelled antibodies $[60,61]$, the use of antibodies as diagnostic or prognostic tools may be limited. Poor contrasts between tumor and non-target tissue are often achieved following prolonged circulation times and slow uptake by tumors [62].

Imaging of radiolabelled derivatives of folic acid may offer greater tissue selectivity. Folic acid derivatives conjugated to a variety of metal chelates have allowed non-invasive detection of FR $\alpha$-positive tumors in both animal models and patients [62]. Of these probes, the most extensively studied is ${ }^{111}$ In-DPTA-folate, which demonstrated good on-target to off-tumor contrast in mouse models, leading to a phase I/II trial. Patients with newly diagnosed or suspected recurrent ovarian cancer were imaged by single-proton emission computed tomography (SPECT) using this agent. Newly diagnosed malignancies were detected at a sensitivity of $100 \%(n$ $=7$ ), although detection of recurrent disease was more problematic. Overall, this agent appeared to be safe,

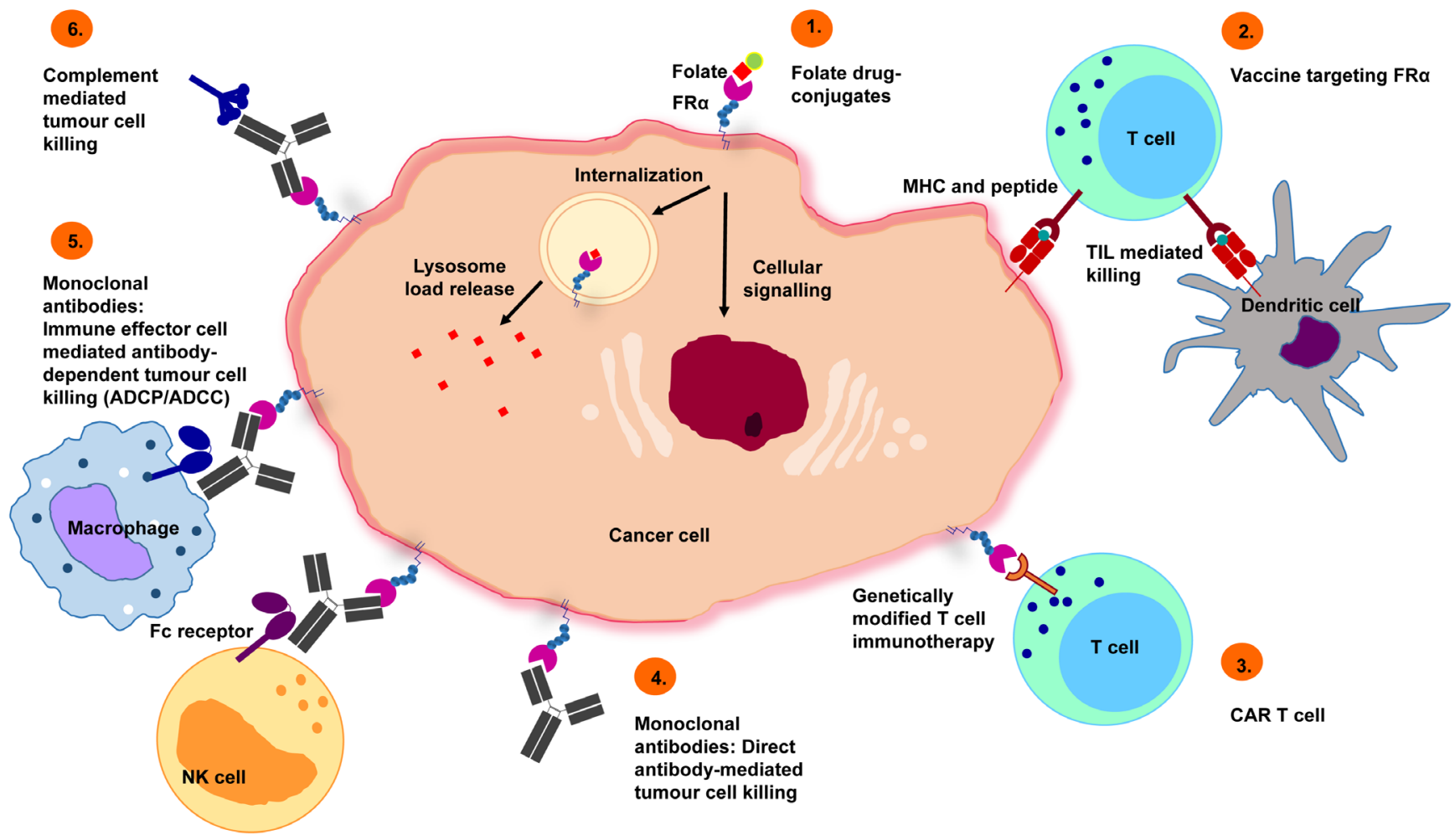

Figure 3: Potential treatment approaches targeting FR $\alpha$. 1) Folate drug-conjugates: chemotherapeutic agents, such as vintafolide, have been conjugated to folate for FR $\alpha$ targeting. 2) Vaccines targeting FR $\alpha$ : autologous dendritic cells engineered with FR $\alpha$ mRA commence an anti-FR $\alpha$ immune response, mediated by T-cells. 3) Chimeric antigen receptor (CAR) T cells: CAR T cells recognizing FR $\alpha$ trigger tumor cell killing. 4) Monoclonal antibodies (direct effects): Specific recognition of FR $\alpha$ lead to inhibition of downstream signaling events that cause tumor cell death. 5) Monoclonal antibodies (immune effector cell engagement): antibodies link FR $\alpha$-expressing tumor cells with immune effector cells that bear Fc receptors, potentiate effector cell activation and target-neutralizing functions by engendering antibody-dependent effector cell-mediated cytotoxicity (ADCC), phagocytosis (ADCP) or 6) complement-dependent cytotoxicity (CDC) activation. 
Table 2: Clinical trials of $F R \alpha$-targeting vaccines and CAR $T$ cells.

\begin{tabular}{|c|c|c|c|c|c|c|c|}
\hline Drug Name & $\begin{array}{l}\text { Alternative } \\
\text { Name(s) }\end{array}$ & $\begin{array}{l}\text { Tumor } \\
\text { Type }\end{array}$ & Trial Design & $\begin{array}{l}\text { Efficacy } \\
\text { Outcome }\end{array}$ & Safety Outcome & \begin{tabular}{|l} 
Imaging \\
Outcome
\end{tabular} & $\begin{array}{l}\text { Reference/Trial } \\
\text { Number }\end{array}$ \\
\hline \multicolumn{8}{|l|}{ Vaccines } \\
\hline $\begin{array}{l}\text { Folate } \\
\text { Immune }\end{array}$ & $\begin{array}{l}\text { EC90/GPI- } \\
0100 / \text { EC17 }\end{array}$ & $\begin{array}{l}\text { Renal cell } \\
\text { carcinoma }\end{array}$ & $\begin{array}{l}\text { Phase I study of } \\
\text { Folate Immune } \\
\text { (EC90 vaccine } \\
\text { administered with } \\
\text { GPI-0100 adjuvant } \\
\text { followed by EC17) } \\
\text { in patients with } \\
\text { renal cell carcinoma }\end{array}$ & $\begin{array}{l}1 / 28 \quad(4 \%) \\
\text { patients had a } \\
\text { PR, 15/28 }(54 \%) \\
\text { had SD }\end{array}$ & $\begin{array}{l}\text { Two DLTs seen } \\
\text { (G4 anaphylaxis } \\
\text { and } r \text { G3 } \\
\text { pancreatitis). Mild } \\
\text { - mod injection } \\
\text { site reactions were } \\
\text { most common AE } \\
\text { during vaccination } \\
\text { phase. Transient } \\
\text { hypersensitivity } \\
\text { reactions were } \\
\text { most common } \\
\text { during treatment } \\
\text { phase }\end{array}$ & N/A & $\begin{array}{l}{[97]} \\
\text { NCT00329368 }\end{array}$ \\
\hline $\begin{array}{l}\text { Folate } \\
\text { Immune }\end{array}$ & $\begin{array}{l}\text { EC90/GPI- } \\
0100 / \mathrm{EC} 17\end{array}$ & $\begin{array}{l}\text { Renal cell } \\
\text { carcinoma }\end{array}$ & $\begin{array}{l}\text { Phase I study of } \\
\text { Folate Immune } \\
\text { (EC90 vaccine } \\
\text { administered with } \\
\text { GPI-0100 adjuvant } \\
\text { followed by } \\
\text { EC17) in patients } \\
\text { with progressive } \\
\text { metastatic renal cell } \\
\text { carcinoma }\end{array}$ & \multicolumn{2}{|c|}{$\begin{array}{l}\text { Trial terminated due to poor patient } \\
\text { accrual }\end{array}$} & N/A & NCT00485563 \\
\hline $\begin{array}{l}\text { Autologous } \\
\text { dendritic } \\
\text { cells } \\
\text { engineered } \\
\text { with FR } \alpha \\
\text { mRNA }\end{array}$ & / & $\begin{array}{l}\text { FR } \alpha+ \\
\text { serous } \\
\text { papillary } \\
\text { ovarian } \\
\text { carcinoma }\end{array}$ & $\begin{array}{l}\text { Single patient report } \\
\text { of a patient with } \\
\text { serous papillary } \\
\text { ovarian carcinoma } \\
\text { at second relapse } \\
\text { (platinum-resistant) } \\
\text { who received a } \\
\text { vaccination regimen } \\
\text { with autologous } \\
\text { dendritic r cells } \\
\text { engineered with } \\
\text { mRNA encoded } \\
\text { FR } \alpha\end{array}$ & $\begin{array}{l}\text { CT before } \\
\text { treatment } \\
\text { and 3 months } \\
\text { after the last } \\
\text { vaccination (13 } \\
\text { months total) } \\
\text { demonstrated } \\
\text { a PR. CA-125 } \\
\text { greatly reduced } \\
4 \text { weeks after the } \\
\text { first vaccination } \\
\text { and were still } \\
\text { at baseline at } \\
11 \text { months after } \\
\text { completion of } \\
\text { vaccination }\end{array}$ & Not reported & N/A & {$[96]$} \\
\hline \multicolumn{8}{|l|}{ CAR T Cells } \\
\hline $\begin{array}{l}\text { CAR-T cells } \\
\text { specific to } \\
\text { FR } \alpha\end{array}$ & / & $\begin{array}{l}\text { Ovarian } \\
\text { cancer }\end{array}$ & $\begin{array}{l}\text { Phase I study of } \\
\text { adoptive transfer } \\
\text { of FR } \alpha \text { redirected } \\
\text { autologous T cells, } \\
\text { either with high- } \\
\text { dose IL-2 (cohort } \\
\text { 1), or followed } \\
\text { by immunization } \\
\text { with allogeneic } \\
\text { peripheral blood } \\
\text { mononuclear cells } \\
\text { (cohort } 2 \text { ), for } \\
\text { recurrent ovarian } \\
\text { cancer }\end{array}$ & $\begin{array}{l}\text { No reduction in } \\
\text { tumor burden } \\
\text { was seen in any } \\
\text { patient }\end{array}$ & $\begin{array}{l}5 / 8(63 \%) \text { patients } \\
\text { in cohort } 1 \\
\text { experienced a G3 } \\
-4 \mathrm{AE}\end{array}$ & $\begin{array}{l}\text { Lack of } \\
\text { specific } \\
\text { localization } \\
\text { of T cells to } \\
\text { tumor was } \\
\text { observed } \\
\text { by tracking } \\
\text { 111 In- } \\
\text { labeled } \\
\text { adoptively } \\
\text { transferred } \\
\text { T cells }\end{array}$ & {$[133]$} \\
\hline
\end{tabular}

AE, adverse event; DLT, dose-limiting toxicity; G, CTCAE grade; PR, partial response; SD, stable disease. Clinical trial number (NCT) available from: http://clinicaltrials.gov. 
and possibly an effective diagnostic tool, although this evaluation was limited by the small sample size of 33 patients [63]. Another folic acid peptide derivative (EC20) conjugated with ${ }^{99 \mathrm{~m}}$ Technetium ( ${ }^{99 \mathrm{~m} T c-E C 20)}$, which is less costly and has a shorter half-life than ${ }^{111}$ In-DPTA-folate, has also demonstrated promising qualities in preclinical models of ovarian cancer [64]. Furthermore, this agent has demonstrated superior FR $\alpha$ affinity and clearance from the blood and kidneys, and has been used to image $>$ 200 patients to date, without any imaging-related adverse events reported [36].

By contrast, using macromolecular dendrimer polychelates conjugated to folic acid in magnetic resonance imaging (MRI) showed improved tumor to non-target contrast in mouse models of ovarian cancer, with specific accumulation in the tumor. This is thought to be due to a reduction in microcapillary permeation by the large probe molecule, and thus a greater relative accumulation in FR $\alpha$-positive tumors [65]. A more recent study demonstrated the clinical promise of FR $\alpha$-specific ultrasmall superparamagnetic iron oxides in MRI of a rat model of breast cancer. This agent was specifically retained in FR $\alpha$-positive breast tumors and may also be useful as a non-invasive tool to diagnose and discriminate FR $\alpha$-positivity [66].

Agents comprising folic acid conjugated to fluorescent dyes have been evaluated. These agents provide good contrast between malignant and healthy tissues in animal models. However, due to the optical qualities of the dyes, surgical opening of the cancer site was required to obtain images. In future it may be possible to use such agents in cutaneous or subcutaneous cancers, or to guide endoscopic or open surgery for cancer [36].

Overall, these imaging agents may allow clinical detection of FR $\alpha$-positive tumors, which may aid diagnosis and disease surveillance. However, improvements in sensitivity and future studies to evaluate prognostic utility are needed to validate this approach as a clinical tool.

\section{Etarfolatide}

Etarfolatide is a ${ }^{99 \mathrm{~m}} \mathrm{Tc}-$ based imaging agent, also known as FolateScan, which has been the subject of many studies in patients with ovarian, kidney, lung cancer and other refractory solid tumors (NCT01686256, NCT01684098) [67]. The purpose of etarfolatide is use as a companion agent with vintafolide, to enable preselection of patients with tumors expressing FR $\alpha$. The administration of folic acid prior to etarfolatide infusion was shown to improve SPECT images, and a phase I clinical study was performed to investigate the safety and pharmacokinetics of etarfolatide up to 7 days following folic acid injection [68]. Etarfolatide has since been used to evaluate the tumor $\mathrm{FR} \alpha$ expression of individuals in a number of trials (NCT00511485, NCT01577654 and NCT01999738).

\section{Folate drug-conjugates}

The first folate-conjugated cytotoxic agent to be evaluated in tumor therapy was a maytansinoid conjugate [69]. Since then, a series of chemotherapy agents has been conjugated to folate for FR $\alpha$ targeting, with varying degrees of success. Key clinical trials are summarized in Table 1 [70].

\section{Vintafolide and other folate conjugates}

Vintafolide, or EC145, is a folate conjugate of desacetylvin-blastinemonohydrazide (DAVLBH), a derivative of the microtubule destabilizing agent vinblastine [71]. Following receptor-mediated endocytosis, the self-immolative disulphide-linker system enables the release of DAVLBH into the tumor cell endosome, leading to inhibition of cell division and induction of cell death $[72,73]$. The safety of vintafolide was first assessed in a phase I clinical study in various solid tumors [74], while multiple phase II and III clinical trials have been conducted in lung and ovarian cancer (NCT00507741, NCT01577654, NCT00722592, NCT00511485 and NCT01170650) [69].

One clinical study, EC-FV-03 (NCT00511485), consisted of a single-arm phase II trial that assessed vintafolide as a single agent in patients with lung adenocarcinoma, who had previously been treated with at least two chemotherapy regimens. Analysis of survival outcomes demonstrated superior median PFS in patients with high FR $\alpha$ tumor expression compared with those with low expression. The median OS also showed a trend towards improvement [75], although the non-randomized study design precluded drawing any firm efficacy conclusion given the likely prognostic value of FR-alpha expression. The randomized, openlabel, phase II TARGET, study (NCT01577654), has also recruited patients with FR $\alpha$-positive non-small cell lung cancer. Preliminary results for vintafolide combined with docetaxel suggest improvement across all efficacy endpoints over docetaxel as single agent in the control arm [76].

Among the multiple clinical studies of vintafolide conducted on ovarian cancer patients, of particular interest is the open-label phase II PRECEDENT study (NCT00722592) [77]. In this trial, patients who had received more than two previous chemotherapeutics were randomized to receive vintafolide and PEGylated liposomal doxorubicin (PLD) or PLD alone until progression or death. Median PFS, compared to PLD treatment alone, was most superior in individuals with higher FR $\alpha$ expression. This was the first combination therapy to suggest a significant prolongation of PFS over standard therapy in platinum-resistant ovarian cancer patients [28]. The fact that FR $\alpha$-negative patients (based 
Table 3: Clinical trials of FR $\alpha$-targeting monoclonal antibodies.

\begin{tabular}{|c|c|c|c|c|c|c|c|}
\hline Drug Name & $\begin{array}{l}\text { Alternative } \\
\text { Name(s) }\end{array}$ & Tumor Type & Trial Design & Efficacy Outcome & Safety Outcome & $\begin{array}{l}\text { Imaging } \\
\text { Outcome }\end{array}$ & $\begin{array}{l}\text { Reference/Trial } \\
\text { Number }\end{array}$ \\
\hline \multirow{8}{*}{ Farletuzumab } & \multirow{8}{*}{ MORab003 } & $\begin{array}{l}\text { Platinum- } \\
\text { resistant } \\
\text { EOC }\end{array}$ & $\begin{array}{l}\text { Phase I dose } \\
\text { escalation study of } \\
\text { weekly farletuzumab }\end{array}$ & $\begin{array}{l}\text { Following } \\
\text { treatment cycle } \\
(4 \text { weeks): No } \\
\text { objective responses. } \\
\text { SD in } 36 \% \text { patients } \\
\text { and CA-125 } \\
\text { reduction in } 16 \%\end{array}$ & $\begin{array}{l}\text { No DLTs. MTD } \\
\text { not reached }\end{array}$ & $\begin{array}{l}\text { Radiolabeled } \\
\text { tracer studies } \\
\text { conducted in } 3 \\
\text { patients showed } \\
\text { significant tumor } \\
\text { uptake }\end{array}$ & $\begin{array}{l}{[105]} \\
\text { NCT00428766 }\end{array}$ \\
\hline & & $\begin{array}{l}\text { Platinum- } \\
\text { sensitive } \\
\text { EOC }\end{array}$ & $\begin{array}{l}\text { Phase II study of } \\
\text { farletuzumab as } \\
\text { single agent or in } \\
\text { combination with } \\
\text { a platinum and } \\
\text { taxane in platinum- } \\
\text { sensitive, recurrent } \\
\text { epithelial ovarian, } \\
\text { fallopian tube or } \\
\text { primary peritoneal } \\
\text { cancer }\end{array}$ & $\begin{array}{l}\text { Farletuzumab alone: } \\
0 \% \text { normalised } \\
\text { CA125, 30\% SD as } \\
\text { best response, } 70 \% \\
\text { PD. Farletuzumab } \\
+ \text { chemotherapy: } \\
80.9 \% \text { normalised } \\
\text { CA } 125 \text {. ORR } 75 \% \text {. } \\
\text { In } 21 \% \text {, the second } \\
\text { progression-free } \\
\text { interval was longer } \\
\text { than the first }\end{array}$ & $\begin{array}{l}\text { Farletuzumab } \\
\text { well-tolerated } \\
\text { as single agent, } \\
\text { without additive } \\
\text { toxicity when } \\
\text { administered with } \\
\text { chemotherapy. } \\
\text { SAEs in } 37 \% \\
\text { patients - 9\% } \\
\text { considered } \\
\text { related to } \\
\text { farletuzumab }\end{array}$ & N/A & $\begin{array}{l}{[107]} \\
\text { NCT00318370 }\end{array}$ \\
\hline & & $\begin{array}{l}\text { Platinum- } \\
\text { sensitive } \\
\text { EOC }\end{array}$ & $\begin{array}{l}\text { Phase Ib safety study } \\
\text { of farletuzumab, } \\
\text { carboplatin and } \\
\text { PLD in patients with } \\
\text { platinum-sensitive } \\
\text { EOC at first or } \\
\text { second relapse }\end{array}$ & $\begin{array}{l}\text { CR in one patient } \\
(7 \%) \text {, PRs in } 10 \\
\text { patients }(67 \%) \text {, SD } \\
\text { in } 4 \text { patients }(27 \%) .\end{array}$ & $\begin{array}{l}\text { Combination } \\
\text { well-tolerated - } \\
\text { no farletuzumab- } \\
\text { related G3-4 } \\
\text { adverse events. }\end{array}$ & N/A & $\begin{array}{l}{[106]} \\
\text { NCT01004380 }\end{array}$ \\
\hline & & $\begin{array}{l}\text { Platinum- } \\
\text { sensitive } \\
\text { EOC }\end{array}$ & $\begin{array}{l}\text { Phase III double- } \\
\text { blind placebo- } \\
\text { controlled study of } \\
\text { weekly farletuzumab } \\
\text { + carboplatin/taxane } \\
\text { in platinum-sensitive } \\
\text { ovarian cancer at } \\
\text { first relapse. }\end{array}$ & $\begin{array}{lr}\text { Median PFS } & 9.0 \\
\text { (placebo), } & 9.5 \\
\text { (farletuzumab } 1.25 \\
\text { mg/kg), and } 9.7 \\
\text { (farletuzumab } 2.5 \\
\text { mg/kg) months } \\
\text { with no statistically } \\
\text { significant } \\
\text { difference between } \\
\text { arms }\end{array}$ & $\begin{array}{l}\text { Most common } \\
\text { AEs across } \\
\text { arms were those } \\
\text { known to be } \\
\text { associated with } \\
\text { chemotherapy. }\end{array}$ & N/A & $\begin{array}{l}{[28]} \\
\text { NCT00849667 }\end{array}$ \\
\hline & & \begin{tabular}{l|} 
\\
Platinum- \\
sensitive \\
recurrent \\
EOC with a \\
low CA125
\end{tabular} & $\begin{array}{l}\text { Phase III global } \\
\text { multicenter double- } \\
\text { blind randomized } \\
\text { placebo-controlled } \\
\text { trial of farletuzumab } \\
+ \text { platinum and a } \\
\text { taxane or PLD in } \\
\text { patients with first } \\
\text { relapse of platinum- } \\
\text { sensitive ovarian } \\
\text { cancer and a low } \\
\text { CA125 }\end{array}$ & Data awaited & Data awaited & N/A & NCT02289950 \\
\hline & & $\begin{array}{l}\text { Platinum- } \\
\text { resistant } \\
\text { EOC }\end{array}$ & $\begin{array}{l}\text { Phase III double- } \\
\text { blind placebo- } \\
\text { controlled study of } \\
\text { weekly farletuzumab } \\
+ \text { paclitaxel in } \\
\text { platinum-resistant } \\
\text { ovarian cancer at } \\
\text { relapse }\end{array}$ & $\begin{array}{l}\text { Predefined criteria } \\
\text { for trial continuation } \\
\text { were not met. }\end{array}$ & Trial terminated & N/A & NCT00738699 \\
\hline & & $\begin{array}{|lr|}\text { FR } \alpha+ & \text { TNBC } \\
\text { with } & \text { low } \\
\text { levels } & \text { of } \\
\text { CA125 } & \\
\end{array}$ & $\begin{array}{l}\text { Phase II trial of } \\
\text { farletuzumab in } \\
\text { FR } \alpha+\text { TNBC with } \\
\text { low levels of CA125 }\end{array}$ & Data awaited & Data awaited & N/A & [78] \\
\hline & & $\begin{array}{l}\text { NSCLC } \\
\text { (adenoCa) }\end{array}$ & $\begin{array}{l}\text { Phase II randomized, } \\
\text { placebo-controlled, } \\
\text { multicenter study } \\
\text { of a platinum } \\
\text { containing doublet } \\
+/ \text { farletuzumab } \\
\text { in stage IV } \\
\text { adenocarcinoma of } \\
\text { the lung }\end{array}$ & Data awaited & Data awaited & $\mathrm{N} / \mathrm{A}$ & NCT01218516 \\
\hline
\end{tabular}




\begin{tabular}{|c|c|c|c|c|c|c|c|}
\hline MOv18 IgG & / & $\begin{array}{l}\text { Ovarian } \\
\text { carcinoma }\end{array}$ & $\begin{array}{ll}\text { Phase I } & \text { single } \\
\text { infusion } & \text { dose- } \\
\text { escalating } & \text { study } \\
\text { of cMOv18 } & \text { IgG } \\
\text { in patients } & \text { with } \\
\text { primary, residual or } \\
\text { recurrent } & \text { ovarian } \\
\text { cancer } & \end{array}$ & $\begin{array}{l}\text { Efficacy outcomes } \\
\text { not reported }\end{array}$ & $\begin{array}{|lr|}\text { Norrar } & \text { DLT } \\
\text { observed. At } & \text { At } \\
\text { doses of } & 550 \mathrm{mg} \\
\text { all patients } \\
\text { experienced } \\
\text { G2 side effects, } \\
\text { including fever, } \\
\text { headacher and } \\
\text { nausea/vomiting } \\
\end{array}$ & N/A & [112] \\
\hline \multirow{3}{*}{${ }^{131} \mathrm{I}-\mathrm{cMOv} 18 \mathrm{IgG} 1$} & \multirow{3}{*}{ / } & $\begin{array}{l}\text { Ovarian } \\
\text { carcinoma }\end{array}$ & \begin{tabular}{|l|} 
Kinetics and tissue \\
distribution of \\
${ }^{13} \mathrm{I}-\mathrm{cMO} 18 \mathrm{IgG} 1 \mathrm{in}$ \\
patients with ovarian \\
carcinoma \\
\end{tabular} & Not reported & Not reported & $\begin{array}{l}\text { Good localisation } \\
\text { in r ovarian } \\
\text { carcinoma tissue }\end{array}$ & {$[33]$} \\
\hline & & $\begin{array}{l}\text { Ovarian } \\
\text { carcinoma }\end{array}$ & \begin{tabular}{|l|} 
Phase I study of i.p. \\
radioimmunotherapy \\
with 131 I-mMOv18 \\
IgG1 in patients with \\
ovarian cancer with \\
minimal residual \\
disease \\
\end{tabular} & $\begin{array}{l}5 / 16 \text { patients had a } \\
\text { CR, 6/16 patients } \\
\text { had } \mathrm{SD} \text { and } 5 / 16 \\
\text { patients had } \mathrm{PD}\end{array}$ & \begin{tabular}{|lr|}
\multicolumn{2}{|l|}{ Minimal } \\
toxicities \\
observed. One \\
patient r mild \\
and $r$ transient \\
bonerrarrow \\
suppression \\
\end{tabular} & N/A & [111] \\
\hline & & $\begin{array}{l}\text { Ovarian } \\
\text { carcinoma }\end{array}$ & $\begin{array}{l}\text { Phase I study } \\
\text { of i.p. and i.v. } \\
\text { radioimmunotherapy } \\
\text { with }{ }_{131} \text { I-cMOv18 } \\
\text { IgG1 in patients with } \\
\text { suspected ovarian } \\
\text { cancer scheduled to } \\
\text { undergo exploratory } \\
\text { laparotomy } \\
\end{array}$ & $\begin{array}{l}\text { Efficacy outcomes } \\
\text { not reported }\end{array}$ & $\begin{array}{l}\text { No normal organ } \\
\text { toxicity }\end{array}$ & $\begin{array}{l}\text { Tumor uptake in } \\
\text { ovarian cancer } \\
\text { tissue } 3.4 \% \text { - } \\
12.3 \% \text { ID } / \mathrm{kg} \text { for } \\
\text { i.p.and } 3.6 \% \text { - } \\
5.4 \% \mathrm{ID} / \mathrm{kg} \text { for i.v. } \\
\text { administration }\end{array}$ & [113] \\
\hline $\begin{array}{l}{ }^{125} \mathrm{I}-, \quad{ }^{123} \mathrm{I}-, \quad{ }^{131} \mathrm{I}- \\
\mathrm{cMOv} 18 \mathrm{IgG} 1\end{array}$ & / & $\begin{array}{l}\text { Ovarian } \\
\text { carcinoma }\end{array}$ & $\begin{array}{l}\text { Study of } \\
\text { simultaneous i.v. } \\
\text { and i.p injection } \\
\text { of radiolabeled } \\
\text { c-MOv18 } \\
\text { (using different } \\
\text { radionuclides in } \\
\text { patients with ovarian } \\
\text { cancer to determine } \\
\text { the optimum way to } \\
\text { deliver radiolabeled } \\
\text { cMOv18 }\end{array}$ & Not reported & No AEs reported & $\begin{array}{l}\text { No significant } \\
\text { differences found } \\
\text { in tumor:normal } \\
\text { tissue and } \\
\text { tumor:blood ratios } \\
\text { for both i.v. and } \\
\text { i.p routes. Tumor } \\
\text { uptake varied } \\
\text { between patients } \\
\text { and within same } \\
\text { patient }\end{array}$ & {$[61]$} \\
\hline MOv18 IgE & / & $\begin{array}{l}\text { FR } \alpha+ \\
\text { advanced } \\
\text { tumors }\end{array}$ & $\begin{array}{lll}\text { Phase I: First in } \\
\text { human study of } \\
\text { MOv18 IgE in } \\
\text { patients with FR } \alpha+ \\
\text { advanced cancer }\end{array}$ & Data awaited & Data awaited & N/A & NCT02546921 \\
\hline
\end{tabular}

AE, adverse event; cMOv18, chimeric MOv18; CR, complete response; DLT, dose-limiting toxicity; EOC, epithelial ovarian cancer; G, CTCAE grade; i.p., intraperitoneal; i.v., intravenous; MTD, maximum tolerated dose; NSCLC, nonsmall cell lung cancer; ORR, overall response rate; PD, progressive disease; PFS, progression-free survival; PLD, pegylated liposomal doxorubicin; PR, partial response; SAE, serious adverse event; SD, stable disease; TNBC, triple negative breast cancer. Clinical trial numbers (NCT) available from: http://clinicaltrials.gov.

on etarfolatide imaging) did not benefit from vintafolide and PLD combination therapy, whereas patients with highly FR $\alpha$-positive tumors did, supported the strategy of using an imaging agent to identify the FR $\alpha$-positive patient population for FR $\alpha$-targeted therapy. However, the subsequent phase III PROCEED trial, designed to further evaluate the clinical efficacy of vintafolide combined with PLD (NCT01170650) was discontinued at an interim analysis because the experimental arm did not meet the pre-specified primary outcome for PFS improvement required [78].

Following vintafolide, several additional folateconjugated agents have been studied. EC0225, a folate conjugated to both a vinca alkaloid and mitomycin, was evaluated in a phase I trial which determined the maximum tolerated dose (MTD) (NCT00441870) [79].
Results are awaited from a phase I/II trial (NCT00546247) of BMS-753493 (Epofolate), a folate conjugate of epothilone $\mathrm{A}$, which is a microtubule stabilizing agent $[80,81]$. EC0489, an analogue of vintafolide, has been shown to have reduced hepatic clearance [82] and its MTD was evaluated in a phase I trial of metastatic tumors (NCT00852189). EC1456, a folic acid-tubulysin smallmolecule drug conjugate, is currently undergoing phase I trial in patients with advanced NSCLC, ovarian cancer and TNBC (NCT01999738). IMGN853, an anti-FR $\alpha$ mAb conjugated with the maytansinoid, DM4, is now being evaluated in a number of phase I clinical trials to evaluate its safety and pharmacokinetics/pharmacodynamics alone (NCT01609556), and in combination with chemotherapy and bevacizumab (NCT02606305), in patients with EOC and other FR $\alpha$-positive tumors. Furthermore, a 
phase II trial, to compare the efficacy of IMGN853 to standard chemotherapies, is recruiting patients with FR $\alpha$ positive tumors (NCT02631876). Folate-conjugated carboplatin was not considered a promising therapy due to neutralization by folate receptor-mediated endocytosis [83], but several other microtubule poisons have shown moderate promise in in vitro and in vivo models [84, 85].

Unlike anti-FR $\alpha$ antibodies, folate conjugates target both FR $\alpha$ and the functional form of FR $\beta$. This could potentially enable the targeting of tumors that are low in FR $\alpha$ but high in FR $\beta$, including tumors that are infiltrated by large numbers of tumor-associated macrophages (TAMs), known to express FR $\beta$. Targeting pro-tumoral TAMs with FR $\beta$-specific agents is a widening avenue of research discussed in detail in other publications [86-89].

The bi-specificity of folate drug-conjugates might reduce the selectivity of these drugs for tumor cells, but may potentially expand the range of targets to include elements of the tumor microenvironment. A potential disadvantage of folate-conjugated drug delivery is that binding is competitively-inhibited by excess serum free folate. A further potential issue is the exposure of FR $\alpha$ expressed in the apical membrane of the proximal renal tubules following filtration of low molecular weight (LMW) folate conjugates [90]. While this has not adversely affected clinical translation of folate conjugates, it may affect the clinical application of LMW folate conjugate-based radiopharmaceuticals for targeted radiotherapy.

\section{Anti-FR $\alpha$ small molecule drugs}

Conventional anti-folate drugs, such as pemetrexed and methotrexate, are often carried by the high capacity RFC, which is ubiquitously expressed on normal and tumor cells, leading to non-specific activity and associated reductions in patient tolerability. Therefore, anti-folate thymidylate synthase (TS) and glycinamide ribonucleotide formyl transferase (GARFTase) inhibitors, with negligible affinity for RFC and high-affinity for FR $\alpha$, have been developed. These anti-FR $\alpha$ small molecules are thought to be more tumor-targeted, due to the restricted expression of FR $\alpha$ on normal tissue on apical membranes away from the bloodstream [91, 92]. Examples of anti-FR $\alpha$ TS inhibitors include CB300638 and ONX-0801. Preclinical studies of these agents have demonstrated antitumor efficacy in FR $\alpha$-expressing tumors, and reduced transportation through RFC, which is expected to confer reduced patient toxicity $[91,93,94]$. A limitation for antiFR $\alpha$ small molecules may be the level of FR $\alpha$ expression by target tumor cells, which needs to be sufficient to transport adequate amounts of the drug into the cell in order to inhibit TS and cause cell death. Much of the preclinical studies have used cell lines and therefore future work will be required to determine whether the expression levels of FR $\alpha$ are sufficient for functional effects against patient tumors [95]. A phase I trial of ONX-0801 is now recruiting patients with solid tumors, expected to have high FR $\alpha$ expression, such as EOC patients, in order to evaluate the safety and efficacy of two dosing schedules (NCT02360345).

\section{Vaccines targeting FR $\alpha$}

Increased immunity to FR $\alpha$ has been reported in patients with FR $\alpha$-expressing ovarian cancer in comparison to healthy controls, suggesting that this may be a target for cell-based and peptide immunotherapies [23]. Key clinical trials are summarized in Table 2 [70].

A case report of a single patient with ovarian carcinoma, vaccinated with autologous dendritic cells that were engineered with mRNA-encoded FR $\alpha$, demonstrated a vaccine-induced $\mathrm{T}$ cell reactivity, resulting in more than $50 \%$ of tumor regression, as well as a reduction of tumor markers levels, suggesting this strategy may hold promise as a cancer treatment [96]. A FR $\alpha$-targeted hapten immunotherapeutic regimen known as 'Folate Immune', which combines folate-targeted vaccine EC90, together with an adjuvant, GPI-0100, and a folate-hapten conjugate EC17, was designed to convert poorly immunogenic tumors to highly immunogenic tumors. Patients first underwent vaccination with EC90 and GPI-0100 adjuvant to stimulate production of specific antibodies, and were then treated with EC17, which is thought to bridge antibodies with FR $\alpha$-expressing tumor cells and trigger antibody-dependent cellular cytotoxicity and/or phagocytosis (ADCC/ADCP). A phase I study confirmed that this regimen was well tolerated in 33 patients, with mild to moderate injection site reactions being the most common adverse effects reported [97]. A phase II trial was then initiated in 2012to evaluate this therapeutic strategy in patients with metastatic renal cell carcinoma, but has since been terminated due to low patient accrual (NCT00485563).

\section{Oncolytic virus therapy}

Virotherapy is a treatment approach using wild type or genetically engineered viruses [98]. An attenuated measles virus has been evaluated pre-clinically as FR $\alpha$ targeting treatment for ovarian cancer. The anti-tumor activity of oncolytic measles virus highly specific for FR $\alpha$ $(\mathrm{MV}-\alpha \mathrm{FR})$ was tested in a xenograft model of ovarian cancer. Treatment of human ovarian cancer-bearing mice with MV- $\alpha$ FR resulted in significant inhibition of tumor growth compared to controls and $50 \%$ of mice showed complete regression of tumors. These findings suggested the merit of clinically testing the oncolytic virotherapy approach in FR $\alpha$-expressing tumors [99]. 


\section{Monoclonal antibodies}

Monoclonal antibodies (mAbs) can target tumorassociated antigens, such as FR $\alpha$, on the surface of tumor cells. They can mediate specific anti-tumor activity either by blocking cell signaling or by eliciting immune-mediated cell killing by engaging effector cells or complement. Examples of clinical trials of monoclonal antibodies directed against FR $\alpha$ are summarized in Table $3[70]$.

\section{Farletuzumab}

$\mathrm{A} \mathrm{mAb}$ that has been widely studied in ovarian and lung cancers is farletuzumab, (MORab003). It is a fully humanized IgG1 antibody specific for $\mathrm{FR} \alpha$. Farletuzumab does not prevent binding of folate to its receptors, nor does it inhibit the transport of folate into the cell via the receptor. Instead, in vitro studies have demonstrated that farletuzumab exhibits activity against FR $\alpha$-expressing tumor cells by a number of mechanisms. These include tumor cell killing by antibody-dependent cellular cytotoxicity (ADCC) and complement-dependent cytotoxicity (CDC), sustained tumor cell autophagy, and inhibition of Lyn kinase substrate phosphorylation [100104].

Farletuzumab was first given as monotherapy in a phase I trial in 25 patients with platinum-resistant ovarian cancer (NCT00428766). No dose-limiting toxicities (DLTs) were observed, and dose escalation was continued to a maximum $400 \mathrm{mg} / \mathrm{m}^{2}$ dose [105]. Safety of farletuzumab, in combination with carboplatin and liposomal doxorubicin, was then demonstrated in a phase $\mathrm{Ib}$ study in patients with platinum-sensitive ovarian cancer (NCT01004380) [106]. In a subsequent phase II study, patients with the same disease were given farletuzumab combined with carboplatin and a taxane, followed by farletuzumab maintenance therapy (NCT00318370). Response rates comparing favorably with historical controls were observed. Overall in these trials, farletuzumab was well tolerated as a single-agent, and did not seem to confer additive toxicity when combined with chemotherapy [107].

Following these promising results, a large phase III trial in patients with platinum-sensitive recurrent ovarian cancer was carried out (NCT00849667). In this trial, farletuzumab, in combination with carboplatin and a taxane, was compared to carboplatin/taxane treatment alone. The primary endpoint of improved PFS was not met, however subsequent analysis suggested an improved PFS in some patient subgroups given higher doses, and in those with lower CA125 levels [28]. Farletuzumab in combination with paclitaxel was also compared to paclitaxel alone in patients with platinum-resistant ovarian cancer in a second phase III study (NCT00738699), but this trial was discontinued early for futility.

Given that patients with high FR $\alpha$-expressing tumors may derive greater benefit from farletuzumab therapy than those with low expression in tumors, future trials may involve the stratification of patients based on their tumor FR $\alpha$ expression. In fact, the manufacturer of farletuzumab has announced the development of a diagnostic assay to better identify patients with high FR $\alpha$ expression [108]. Furthermore, a phase II study comparing farletuzumab, in combination with carboplatin and paclitaxel, or with carboplatin and liposomal doxorubcin, is currently recruiting patients with platinum-sensitive ovarian cancer and low CA125 (NCT02289950). Another phase II trial will be conducted in patients with FR $\alpha$-positive TNBC who have low serum levels of CA125 [109].

The clinical efficacy of farletuzumab, in combination with platinum-containing chemotherapy has also been evaluated in non-small-cell lung cancer. This phase II study (NCT01218516) enrolled 130 patients with stage IV adenocarcinoma of the lung and has now completed, although results are yet to be published.

\section{MOv18 IgG1}

The MOv18 IgG1 murine monoclonal antibody was generated by immunization of mice with a surgical specimen of human ovarian carcinoma [32]. The FR $\alpha$ specific variable regions of the resultant antibody were cloned, and the murine $\gamma 1$-heavy chains and $\kappa$-light chains were subsequently replaced with their human equivalents to engineer a chimeric version of MOv18 IgG [110]. Previous clinical studies of MOv18 IgG (either murine or chimeric) administered to ovarian cancer patients have suggested therapeutic benefit with no overt toxicity.

The first clinical administration of MOv18 IgG1 was as a radiolabeled murine antibody $\left({ }^{131} \mathrm{I}-\mathrm{MOv} 18 \mathrm{IgG} 1\right)$ in 1991. The main aim of this study was to investigate the feasibility of radioimmunoscintigraphy (RIS, the administration of a radiolabelled antibody against a tumor surface marker, for the purpose of imaging the tumor and any metastases). Another objective was to evaluate biodistribution of MOv18 IgG1 for further therapeutic applications [60]. A total of 30 patients with ovarian carcinoma were given ${ }^{131} \mathrm{I}-\mathrm{MOv} 18 \mathrm{IgG} 1$ either intravenously (i.v.) $(n=20)$ or intraperitoneally (i.p.) $(n$ $=10$ ). High tumor uptake, a good tumor to background ratio and low non-specific uptake in non-affected organs were observed, with i.p. administration superior to i.v. administration. These findings suggested that MOv18 IgG1 represented a promising $\mathrm{mAb}$ for RIS in ovarian cancer.

Subsequently the same ${ }^{131}$ I-radiolabelled murine antibody was administered as i.p. radioimmunotherapy to 16 ovarian cancer patients with minimal residual disease [111]. Efficacy was observed, with 5 complete responses and 5 patients demonstrating stable disease. In addition 
the toxicity was reported to be low with only one patient showing mild and transient bone marrow suppression. However, human anti-mouse antibody (HAMA) production was demonstrated in $94 \%$ of patients.

In order to reduce HAMA, a chimeric MOv18 IgG1 was generated, and radiolabeled with either ${ }^{131} \mathrm{I}$ or ${ }^{125} \mathrm{I}$, before administration to 24 patients with ovarian carcinoma [33]. Six days after injection, the antibody was demonstrated to localize well in ovarian carcinoma tissue with a mean tumor to normal tissue ratio of 6.7 , indicating a prolonged accumulation in the tumor relative to normal tissues. In view of these positive findings, the safety of a single $i . v$. infusion of increasing doses $(5-75 \mathrm{mg})$ of chimeric MOv18 IgG1 was subsequently evaluated in a phase I study of 15 ovarian carcinoma patients [112]. Administration of MOv18 IgG1 was demonstrated to be safe with no significant changes in hematological, biochemical, or urine profiles detected. However, at doses of $50 \mathrm{mg}$ and above all patients experienced minor (World Health Organization, WHO grade 2) side effects, including fever, headache, and nausea/vomiting. Interestingly, no human anti-chimeric antibody (HACA) response was detected up to 12 weeks post injection. These findings suggested that targeting of FR $\alpha$ with chimeric MOv18 IgG1 was safe and that this $\mathrm{mAb}$ represented a promising therapeutic for the treatment of ovarian carcinoma.

Since ovarian cancer is mainly limited to the peritoneal cavity, locoregional delivery of therapeutics can be an option. Therefore the influence of the route of administration (i.v. or i.p.) of radiolabeled chimeric MOv18 IgG1 was investigated in two studies $[61,113]$. In the first study, ${ }^{131}$ I-MOv18 IgG1 was administered to 12 patients with ovarian cancer. Scintigraphic images after i.p. administration showed better accumulation in ovarian cancer lesions compared with after i.v. administration. Furthermore, there was no normal organ toxicity. This study concluded that the i.p. route of administration was safe and seemed to be preferable to i.v. administration [113]. In the second study 15 patients received chimeric MOv18IgG1 labeled with ${ }^{131} \mathrm{I},{ }^{125} \mathrm{I}$ and ${ }^{123} \mathrm{I}$, either via the i.p. or i.v. route. No adverse events and no HACA response were reported. Furthermore, in contrast to the previous study, no advantage could be demonstrated for the i.p. route of administration with respect to tumor uptake; however, it was suggested that it may be the preferred route with respect to bone marrow toxicity since the area under the curve (AUC) was significantly lower for the i.p. versus the $i . v$.route [61].

In summary, numerous clinical studies conducted with murine or chimeric MOv18 IgG1 to date suggest that targeting the tumor antigen FR $\alpha$ with a therapeutic $\mathrm{mAb}$ is safe, with minimal toxicities observed across all studies. However, some studies have suggested superior tumor targeting when the antibody was administered locoregionally to the tumor, perhaps indicating relatively poor tumor penetrance of MOv18 IgG1 when administered via the $i . v$. route. This suggests the possible benefit of undertaking antibody engineering strategies, including re-engineering approaches or changing the isotype of the antibody, with the aim of improving bioactivity, potency or tumor penetrance aimed at enhancing antibody efficacy.

\section{MOv19 and derivatives}

The mAb MOv19 was selected from the same fusion from which MOv18 was derived. MOv19 and LK26 (the murine mAb from which the fully humanized Farletuzumab was derived) recognize the same or overlapping epitopes on FR $\alpha$, but independent from the epitope recognized by MOv18, as detected by competition assay in Biacore analysis and ELISA $[32,114]$.

Chimeric versions of MOv18 and MOv19 IgG antibodies, similarly to Farletuzumab, mediate both ADCC [115] and low levels of CDC [116] in vitro. However, when the two chimeric mAbs were mixed, a significant increase in tumor cell killing was observed of up to $50 \%$. This value increased to $70 \%$ after neutralization of CD46 and CD59 (membrane C regulatory molecules) without an appreciable change of ADCC. These results suggest that complement can contribute to the killing of ovarian carcinoma cells induced by the mixture of cMOv18 and cMOv19.

Several different derivatives of MOv19 have been evaluated in different therapeutic applications. Completely human Fab fragments against FR $\alpha$ were produced by using phage display and among them one, named $\mathrm{C} 4$, exhibited good specificity [117]. The human $\mathrm{C} 4$ in $\mathrm{scFv}$ format, after adequate optimization, resulted in CAR redirection [118].

By applying epitope imprinting selection [119], a method that enables isolation of antibodies with the same specificity of a pre-existing antibody, a human Fab (AFRA5), recognizing a FR $\alpha$ epitope overlapping with that of MOv19, was identified [120]. After optimization of the lead reagent, a chemical dimer, named AFRADFM5.3, was considered suitable for further in vivo preclinical evaluation in the perspective of a clinical use. In fact, an antibody fragment, in a dimer format that stabilizes binding as soon as the antigen-antibody complex is formed on the target tumor, might be the reagent of choice for i.p. radioimmunotherapy of ovarian cancer because of its relatively small size, which should favor tumor penetration and fast clearance. Due to its fast and high tumor uptake, ${ }^{131}$ I-AFRA-DFM5.3 resulted in more than $50 \%$ of treated animals cured in a preclinical intraperitoneal model [121]. The human origin of AFRADFM5.3 and its efficacy when delivered locoregionally as an ${ }^{131} \mathrm{I}$ reagent, together with evidence of the feasibility and acceptable toxicity profile of ovarian cancer treatment with anti-FR mAbs, could provide the basis for rational design of new therapeutic modalities. 


\section{MOv18 IgE}

MOv18 IgE is an anti-FR $\alpha$ chimeric IgE antibody, engineered from the variable heavy and light chain regions of MOv18 IgG1 in order to investigate the hypothesis that IgE antibodies may offer advantages as immunotherapeutic agents against cancer compared to their IgG counterparts [122]. The rationale for using IgE antibodies against cancer stems from the unique properties of this class, which make it a critical contributor to allergic and parasitic immune responses. These properties include the exceptionally high affinity of $\mathrm{IgE}$ to its $\mathrm{Fc}$ receptors (FceRI and CD23), the lack of an inhibitory IgE receptor, and the significantly longer half-life of $\operatorname{IgE}$ in tissues compared to IgG1, which results in improved local retention of $\operatorname{IgE}$. IgE antibodies are thus able to confer potent immune responses by activating tumor-resident immune effector cells [123].

To date, a number of in vivo models have been used to evaluate the efficacy of MOv18 IgE. Firstly, immunodeficient (SCID) mice challenged subcutaneously (s.c.) with FR $\alpha$-expressing human ovarian carcinoma cells, were treated with human peripheral blood lymphocytes (PBLs) and MOv18 IgE or IgG1 antibodies i.v. [122]. Secondly, a xenograft mouse model was set-up using patient-derived FR $\alpha$-expressing human ovarian carcinoma, and mice were given human peripheral blood mononuclear cells (PBMCs) i.p. with MOv18 IgE or IgG1 antibodies [124-126]. MOv18 IgE afforded superior anti-tumor efficacy and animal survival, compared with its IgG1 counterpart, in both models.

These studies also provided evidence that MOv18 IgE efficacy may be mediated via anti-tumor effector cell functions in vivo: addition of PBMCs was required for the observed protective effect and this efficacy was ablated upon depletion of monocytes; monocytic infiltration was observed in tumor sections from mice treated with MOv18 $\mathrm{IgE}$; and large areas of tumor necrosis were detected following MOv18 IgE treatment $[122,126]$. MOv18 IgEmediated tumor cell killing by human monocytes and eosinophils was also confirmed in vitro by ADCC/ADCP $[126,127]$. Emerging evidence point to the capacity of $\operatorname{IgE}$ antibodies to activate host immune effector cells against cancer and support its anti-tumor efficacy [128-131]. This agent is now being translated for clinical testing in FR $\alpha$ expressing carcinomas.

\section{$T$ cell activating strategies}

The possibility to combine the antibody specificity with the potency of $\mathrm{T}$ cell weapons to treat tumors, independently from the $T$ cell receptor (TcR)-defined specificity, and expression of human leukocyte antigen (HLA) on cancer cells, has been explored and specific reagents for $\mathrm{T}$ cell retargeting were developed. Among different approaches, the most promising are the use of bi-specific antibodies (BsAbs), T-cell engineering to create chimeric antigen receptors (CARs), as well as combinations with immune checkpoint inhibitors.

Adoptive transfers of ex vivo $\mathrm{T}$ cells armed with the BsAb OC/TR (MOv18 x anti-CD3) [132] or of CARengineered T cells recognizing FR $\alpha$ [133] (Table 2) were among the first clinical attempts with these therapeutic tools.

In a phase I/II study, among the 28 ovarian cancer patients treated intraperitoneally with OC/TR-armed activated $\mathrm{T}$ cells and IL-2, response to treatment could be assessed in 26 patients by explorative laparotomy. The overall intraperitoneal response rate was $27 \%$. The complete responses seen in three patients lasted 26 months in one patient, 23 months in the second, and 18 months in the third [132]. On the contrary the outcome of the phase I clinical trial with a FR $\alpha$-specific CAR T cell treatment was discouraging with no response observed in any patient and the presence of significant toxicities [133]. It is noteworthy that both trials have been conducted using the anti-FR $\alpha$ murine monoclonal antibody MOv18 (see further discussion of this antibody below) and that in the OC/TR trial almost all the patients developed a HAMA response that precluded further treatment [134] and in the CAR trial an inhibitory factor developed in the serum of three of six patients tested over the period of treatment, which significantly reduced the ability of gene-modified $T$ cells to respond against $F R \alpha$ positive tumor cells [133].

Even if no clinical results are at present available with these anti-FR $\alpha$ tools, advances in protein engineering and increased knowledge in T cell biology have enabled the rise of both BsAbs and CARs from inefficient first generation reagents to promising molecules for cancer treatment. In particular, first generation CARs failed because of poor $\mathrm{T}$ cell expansion and adverse effects; new second and third generation CARs have solved at least in part these problems and good pre-clinical in vivo results, i.e. tumor regression, longer persistence in circulation and better localization towards the tumor, have been obtained with MOv19-based CAR constructs containing the costimulatory motif of CD137 or CD27 [118, 135].

Another approach, which has recently seen increased interest, is the use of antibodies targeting immune cell checkpoints that negatively regulate antitumor immunity [136]. Ipilimumab targets cytotoxic T lymphocyte-associated antigen 4 (CTLA-4), which is involved in an alternative interaction between $\mathrm{T}$ cells and antigen-presenting cells (APCs) that inhibits T cell effector functions. Similarly, nivolumab and pembrolizumab target the interaction between programmed cell death receptor 1 (PD-1), which is expressed on activated effector cells such as T cell, B cells and other myeloid cells, and its ligand PD-L1, which is expressed on tumor cells and APCs. Treatment with these immune checkpoint-targeting antibodies prevents the attenuation of $\mathrm{T}$ cell activation and 
thereby enhances anti-tumor immunity. Ipilimumab and nivolumab have shown significant efficacy in patients with metastatic melanoma and are now widely approved for treatment of this solid tumor. Clinical trials in patients with other tumor types, including ovarian, lung and breast, are now underway and demonstrating promising results [137-140]. Thus, the combination of checkpoint inhibitors and FR $\alpha$-targeting strategies may well lead to greater therapeutic success.

\section{CONCLUSIONS}

Insights into tumor expression and distribution of $\mathrm{FR} \alpha$ and its emerging roles in cancer growth and metastasis are now focusing renewed interest on this tumorassociated antigen as a potential target and tumor marker for solid tumours such as ovarian, lung and basal breast cancers. There is an unmet need in these malignancies, associated with particularly poor prognosis, for further treatment options as well as biomarkers (predictive and prognostic). Future focus on FR $\alpha$ offers real potential for the development of targeted cancer therapies. Past and ongoing clinical evaluations of FR $\alpha$-targeted therapies, such as vintafolide and farletuzumab, allow for cautious optimism, but suggest that both improved patient selection and optimised modes of action are still needed.

Low levels of FR $\alpha$ expression in most normal tissues predict a low probability of significant toxicity for these agents, supported by clinical experience so far with treatment strategies targeted using folate and antibodies. $\mathrm{FR} \alpha$ expression in tumor may serve as both a predictive marker to guide patient selection for such strategies, and also as a potential prognostic indicator. Furthermore, serum detection of circulating soluble antigen levels might also serve as an effective diagnostic or prognostic marker, and potentially an indicator of treatment response. These possible uses still require further study in FR $\alpha$-expressing malignant indications.

A range of novel immunotherapeutic modalities, including vaccines, oncolytic viruses, monoclonal antibodies and adoptive T-cell strategies, with novel mechanisms of action, are in preclinical or clinical studies. Perhaps those agents with enhanced immune activating properties, more resistant to tumor-associated immune suppressive mechanisms, may in future become effective strategies against FR $\alpha$-expressing tumors.

\section{ACKNOWLEDGMENTS}

The authors acknowledge support by Breast Cancer Now (147) - the UK's largest breast cancer charity - created by the merger of Breast Cancer Campaign and Breakthrough Breast Cancer; Cancer Research UK (C30122/A11527; C30122/A15774); the Medical Research Council (MR/L023091/1); the Academy of Medical Sciences; CR UK//NIHR in England/DoH for
Scotland, Wales and Northern Ireland Experimental Cancer Medicine Centre (C10355/A15587); CR UK/ EPSRC/MRC/NIHR KCL/UCL Comprehensive Cancer Imaging Centre (C1519/A10331). The research was supported by the National Institute for Health Research (NIHR) Biomedical Research Centre based at Guy's and St Thomas' NHS Foundation Trust and King's College London. The views expressed are those of the author(s) and not necessarily those of the NHS, the NIHR or the Department of Health. The authors are solely responsible for the decision to publish, and preparation of the manuscript.

\section{CONFLICTS OF INTEREST}

The authors declare that they have no conflicts of interest.

\section{REFERENCES}

1. Locasale JW. Serine, glycine and one-carbon units: cancer metabolism in full circle. Nat Rev Cancer. 2013; 13:572583.

2. Gueant JL, Namour F, Gueant-Rodriguez RM and Daval JL. Folate and fetal programming: a play in epigenomics? Trends Endocrinol Metab. 2013; 24:279-289.

3. Kerek R, Geoffroy A, Bison A, Martin N, Akchiche N, Pourie G, Helle D, Gueant JL, Bossenmeyer-Pourie C and Daval JL. Early methyl donor deficiency may induce persistent brain defects by reducing Stat3 signaling targeted by miR-124. Cell Death Dis. 2013; 4:e755.

4. Blom HJ and Smulders Y. Overview of homocysteine and folate metabolism. With special references to cardiovascular disease and neural tube defects. J Inherit Metab Dis. 2011; 34:75-81.

5. Matherly LH and Goldman DI. Membrane transport of folates. Vitam Horm. 2003; 66:403-456.

6. Zhao R, Diop-Bove N, Visentin M and Goldman ID. Mechanisms of membrane transport of folates into cells and across epithelia. Annu Rev Nutr. 2011; 31:177-201.

7. Ledermann JA, Canevari S and Thigpen T. Targeting the folate receptor: diagnostic and therapeutic approaches to personalize cancer treatments. Ann Oncol. 2015; 26:20342043.

8. Salazar MD and Ratnam M. The folate receptor: what does it promise in tissue-targeted therapeutics? Cancer Metastasis Rev. 2007; 26:141-152.

9. Kelemen LE. The role of folate receptor alpha in cancer development, progression and treatment: cause, consequence or innocent bystander? Int J Cancer. 2006; 119:243-250.

10. Toffoli G, Cernigoi C, Russo A, Gallo A, Bagnoli M and Boiocchi M. Overexpression of folate binding protein in ovarian cancers. Int J Cancer. 1997; 74:193-198. 
11. Shi H, Guo J, Li C and Wang Z. A current review of folate receptor alpha as a potential tumor target in non-small-cell lung cancer. Drug Des Devel Ther. 2015; 9:4989-4996.

12. Boogerd LS, Boonstra MC, Beck AJ, Charehbili A, Hoogstins CE, Prevoo HA, Singhal S, Low PS, van de Velde CJ and Vahrmeijer AL. Concordance of folate receptor-alpha expression between biopsy, primary tumor and metastasis in breast cancer and lung cancer patients. Oncotarget. 2016; doi: 10.18632/oncotarget.7856.

13. O'Shannessy DJ, Somers EB, Maltzman J, Smale R and $\mathrm{Fu}$ YS. Folate receptor alpha (FRA) expression in breast cancer: identification of a new molecular subtype and association with triple negative disease. Springerplus. 2012; $1: 22$.

14. Siu MK, Kong DS, Chan HY, Wong ES, Ip PP, Jiang L, Ngan HY, Le XF and Cheung AN. Paradoxical impact of two folate receptors, FRalpha and RFC, in ovarian cancer: effect on cell proliferation, invasion and clinical outcome. PLoS One. 2012; 7:e47201.

15. Ritter TE, Fajardo O, Matsue H, Anderson RG and Lacey SW. Folate receptors targeted to clathrin-coated pits cannot regulate vitamin uptake. Proc Natl Acad Sci U S A. 1995; 92:3824-3828.

16. Rothberg KG, Ying YS, Kolhouse JF, Kamen BA and Anderson RG. The glycophospholipid-linked folate receptor internalizes folate without entering the clathrin-coated pit endocytic pathway. J Cell Biol. 1990; 110:637-649.

17. Sabharanjak S and Mayor S. Folate receptor endocytosis and trafficking. Adv Drug Deliv Rev. 2004; 56:1099-1109.

18. Boshnjaku V, Shim KW, Tsurubuchi T, Ichi S, Szany EV, Xi G, Mania-Farnell B, McLone DG, Tomita T and Mayanil CS. Nuclear localization of folate receptor alpha: a new role as a transcription factor. Sci Rep. 2012; 2:980.

19. Figini M, Ferri R, Mezzanzanica D, Bagnoli M, Luison E, Miotti S and Canevari S. Reversion of transformed phenotype in ovarian cancer cells by intracellular expression of anti folate receptor antibodies. Gene Ther. 2003; 10:1018-1025.

20. Darai E, Scoazec JY, Walker-Combrouze F, Mlika-Cabanne N, Feldmann G, Madelenat P and Potet F. Expression of cadherins in benign, borderline, and malignant ovarian epithelial tumors: a clinicopathologic study of 60 cases. Hum Pathol. 1997; 28:922-928.

21. Bagnoli M, Canevari S, Figini M, Mezzanzanica D, Raspagliesi F, Tomassetti A and Miotti S. A step further in understanding the biology of the folate receptor in ovarian carcinoma. Gynecol Oncol. 2003; 88:S140-144.

22. Cerezo A, Guadamillas MC, Goetz JG, Sanchez-Perales S, Klein E, Assoian RK and del Pozo MA. The absence of caveolin-1 increases proliferation and anchorageindependent growth by a Rac-dependent, Erk-independent mechanism. Mol Cell Biol. 2009; 29:5046-5059.
23. Basal E, Eghbali-Fatourechi GZ, Kalli KR, Hartmann LC, Goodman KM, Goode EL, Kamen BA, Low PS and Knutson KL. Functional folate receptor alpha is elevated in the blood of ovarian cancer patients. PLoS One. 2009; 4:e6292.

24. Hansen MF, Greibe E, Skovbjerg S, Rohde S, Kristensen AC, Jensen TR, Stentoft C, Kjaer KH, Kronborg CS and Martensen PM. Folic acid mediates activation of the prooncogene STAT3 via the Folate Receptor alpha. Cell Signal. 2015; 27:1356-1368.

25. Miotti S, Bagnoli M, Tomassetti A, Colnaghi MI and Canevari S. Interaction of folate receptor with signaling molecules lyn and G(alpha)(i-3) in detergent-resistant complexes from the ovary carcinoma cell line IGROV1. J Cell Sci. 2000; 113 Pt 2:349-357.

26. Croucher DR, Hochgrafe F, Zhang L, Liu L, Lyons RJ, Rickwood D, Tactacan CM, Browne BC, Ali N, Chan H, Shearer R, Gallego-Ortega D, Saunders DN, Swarbrick A and Daly RJ. Involvement of Lyn and the atypical kinase SgK269/PEAK1 in a basal breast cancer signaling pathway. Cancer Res. 2013; 73:1969-1980.

27. Kalli KR, Oberg AL, Keeney GL, Christianson TJ, Low PS, Knutson KL and Hartmann LC. Folate receptor alpha as a tumor target in epithelial ovarian cancer. Gynecol Oncol. 2008; 108:619-626.

28. Vergote IB, Marth C and Coleman RL. Role of the folate receptor in ovarian cancer treatment: evidence, mechanism, and clinical implications. Cancer Metastasis Rev. 2015; $34: 41-52$.

29. Parker N, Turk MJ, Westrick E, Lewis JD, Low PS and Leamon CP. Folate receptor expression in carcinomas and normal tissues determined by a quantitative radioligand binding assay. Anal Biochem. 2005; 338:284-293.

30. Ross JF, Chaudhuri PK and Ratnam M. Differential regulation of folate receptor isoforms in normal and malignant tissues in vivo and in established cell lines. Physiologic and clinical implications. Cancer. 1994; 73:2432-2443.

31. Forster MD, Ormerod MG, Agarwal R, Kaye SB and Jackman AL. Flow cytometric method for determining folate receptor expression on ovarian carcinoma cells. Cytometry A. 2007; 71:945-950.

32. Miotti S, Canevari S, Menard S, Mezzanzanica D, Porro G, Pupa SM, Regazzoni M, Tagliabue E and Colnaghi MI. Characterization of human ovarian carcinoma-associated antigens defined by novel monoclonal antibodies with tumor-restricted specificity. Int J Cancer. 1987; 39:297-303.

33. Buist MR, Kenemans P, den Hollander W, Vermorken JB, Molthoff CJ, Burger CW, Helmerhorst TJ, Baak JP and Roos JC. Kinetics and tissue distribution of the radiolabeled chimeric monoclonal antibody MOv18 IgG and F(ab')2 fragments in ovarian carcinoma patients. Cancer Res. 1993; 53:5413-5418, 
34. Elnakat $\mathrm{H}$ and Ratnam M. Distribution, functionality and gene regulation of folate receptor isoforms: implications in targeted therapy. Adv Drug Deliv Rev. 2004; 56:10671084.

35. Low PS and Kularatne SA. Folate-targeted therapeutic and imaging agents for cancer. Curr Opin Chem Biol. 2009; $13: 256-262$.

36. Sega EI and Low PS. Tumor detection using folate receptortargeted imaging agents. Cancer Metastasis Rev. 2008; 27:655-664.

37. Lu Y and Low PS. Immunotherapy of folate receptorexpressing tumors: review of recent advances and future prospects. J Control Release. 2003; 91:17-29.

38. Barretina J, Caponigro G, Stransky N, Venkatesan K, Margolin AA, Kim S, Wilson CJ, Lehar J, Kryukov GV, Sonkin D, Reddy A, Liu M, Murray L, Berger MF, Monahan JE, Morais P, et al. The Cancer Cell Line Encyclopedia enables predictive modelling of anticancer drug sensitivity. Nature. 2012; 483:603-607.

39. Chen YL, Chang MC, Huang CY, Chiang YC, Lin HW, Chen CA, Hsieh CY and Cheng WF. Serous ovarian carcinoma patients with high alpha-folate receptor had reducing survival and cytotoxic chemo-response. Mol Oncol. 2012; 6:360-369.

40. Coward JI, Middleton K and Murphy F. New perspectives on targeted therapy in ovarian cancer. Int J Womens Health. 2015; 7:189-203.

41. Despierre E, Lambrechts S, Leunen K, Berteloot P, Neven P, Amant F, O'Shannessy DJ, Somers EB and Vergote I. Folate receptor alpha (FRA) expression remains unchanged in epithelial ovarian and endometrial cancer after chemotherapy. Gynecol Oncol. 2013; 130:192-199.

42. Crane LM, Arts HJ, van Oosten M, Low PS, van der Zee AG, van Dam GM and Bart J. The effect of chemotherapy on expression of folate receptor-alpha in ovarian cancer. Cell Oncol (Dordr). 2012; 35:9-18

43. Cagle PT, Zhai QJ, Murphy L and Low PS. Folate receptor in adenocarcinoma and squamous cell carcinoma of the lung: potential target for folate-linked therapeutic agents. Arch Pathol Lab Med. 2013; 137:241-244.

44. Iwakiri S, Sonobe M, Nagai S, Hirata T, Wada H and Miyahara R. Expression status of folate receptor alpha is significantly correlated with prognosis in non-small-cell lung cancers. Ann Surg Oncol. 2008; 15:889-899.

45. Nunez MI, Behrens C, Woods DM, Lin H, Suraokar M, Kadara H, Hofstetter W, Kalhor N, Lee JJ, Franklin W, Stewart DJ and Wistuba, II. High expression of folate receptor alpha in lung cancer correlates with adenocarcinoma histology and EGFR [corrected] mutation. J Thorac Oncol. 2012; 7:833-840.

46. O’Shannessy DJ, Yu G, Smale R, Fu YS, Singhal S, Thiel RP, Somers EB and Vachani A. Folate receptor alpha expression in lung cancer: diagnostic and prognostic significance. Oncotarget. 2012; 3:414-425. doi: 10.18632/ oncotarget.489.

47. Bueno R, Appasani K, Mercer H, Lester S and Sugarbaker D. The alpha folate receptor is highly activated in malignant pleural mesothelioma. J Thorac Cardiovasc Surg. 2001; 121:225-233.

48. Nutt JE, Razak AR, O’Toole K, Black F, Quinn AE, Calvert AH, Plummer ER and Lunec J. The role of folate receptor alpha (FRalpha) in the response of malignant pleural mesothelioma to pemetrexed-containing chemotherapy. $\mathrm{Br}$ J Cancer. 2010; 102:553-560.

49. Hartmann LC, Keeney GL, Lingle WL, Christianson TJ, Varghese B, Hillman D, Oberg AL and Low PS. Folate receptor overexpression is associated with poor outcome in breast cancer. Int J Cancer. 2007; 121:938-942.

50. Necela BM, Crozier JA, Andorfer CA, Lewis-Tuffin L, Kachergus JM, Geiger XJ, Kalari KR, Serie DJ, Sun Z, Moreno-Aspitia A, O’Shannessy DJ, Maltzman JD, McCullough AE, Pockaj BA, Cunliffe HE, Ballman KV, et al. Correction: Folate receptor-alpha (FOLR1) expression and function in triple negative tumors. PLoS One. 2015; 10:e0127133.

51. Necela BM, Crozier JA, Andorfer CA, Lewis-Tuffin L, Kachergus JM, Geiger XJ, Kalari KR, Serie DJ, Sun Z, Moreno-Aspitia A, O'Shannessy DJ, Maltzman JD, McCullough AE, Pockaj BA, Cunliffe HE, Ballman KV, et al. Folate receptor-alpha (FOLR1) expression and function in triple negative tumors. PLoS One. 2015; 10:e0122209.

52. Zhang Z, Wang J, Tacha DE, Li P, Bremer RE, Chen H, Wei B, Xiao X, Da J, Skinner K, Hicks DG, Bu H and Tang $\mathrm{P}$. Folate receptor alpha associated with triple-negative breast cancer and poor prognosis. Arch Pathol Lab Med. 2014; 138:890-895.

53. Kelley KM, Rowan BG and Ratnam M. Modulation of the folate receptor alpha gene by the estrogen receptor: mechanism and implications in tumor targeting. Cancer Res. 2003; 63:2820-2828.

54. Anders CK and Carey LA. Biology, metastatic patterns, and treatment of patients with triple-negative breast cancer. Clin Breast Cancer. 2009; 9 Suppl 2:S73-81.

55. Carey LA. Directed therapy of subtypes of triple-negative breast cancer. Oncologist. 2010; 15 Suppl 5:49-56.

56. Brown D and Waneck GL. Glycosyl-phosphatidylinositolanchored membrane proteins. J Am Soc Nephrol. 1992; 3:895-906.

57. Kurosaki A, Hasegawa K, Kato T, Abe K, Hanaoka T, Miyara A, O'Shannessy DJ, Somers EB, Yasuda M, Sekino T and Fujiwara K. Serum folate receptor alpha as a biomarker for ovarian cancer: Implications for diagnosis, prognosis and predicting its local tumor expression. Int $\mathbf{J}$ Cancer. 2016; 138:1994-2002.

58. Mantovani LT, Miotti S, Menard S, Canevari S, Raspagliesi F, Bottini C, Bottero F and Colnaghi MI. Folate binding protein distribution in normal tissues and biological fluids from ovarian carcinoma patients as detected by the 
monoclonal antibodies MOv18 and MOv19. Eur J Cancer. 1994; 30A:363-369.

59. O'Shannessy DJ, Somers EB, Palmer LM, Thiel RP, Oberoi P, Heath R and Marcucci L. Serum folate receptor alpha, mesothelin and megakaryocyte potentiating factor in ovarian cancer: association to disease stage and grade and comparison to CA125 and HE4. J Ovarian Res. 2013; 6:29.

60. Crippa F, Buraggi GL, Di Re E, Gasparini M, Seregni E, Canevari S, Gadina M, Presti M, Marini A and Seccamani E. Radioimmunoscintigraphy of ovarian cancer with the MOv18 monoclonal antibody. Eur J Cancer. 1991; 27:724729.

61. van Zanten-Przybysz I, Molthoff CF, Roos JC, Verheijen RH, van Hof A, Buist MR, Prinssen HM, den Hollander W and Kenemans P. Influence of the route of administration on targeting of ovarian cancer with the chimeric monoclonal antibody MOv18: i.v. vs. i.p. Int J Cancer. 2001; 92:106114.

62. Ke CY, Mathias CJ and Green MA. Folate-receptor-targeted radionuclide imaging agents. Adv Drug Deliv Rev. 2004; 56:1143-1160.

63. Siegel BA, Dehdashti F, Mutch DG, Podoloff DA, Wendt R, Sutton GP, Burt RW, Ellis PR, Mathias CJ, Green MA and Gershenson DM. Evaluation of 111In-DTPA-folate as a receptor-targeted diagnostic agent for ovarian cancer: initial clinical results. J Nucl Med. 2003; 44:700-707.

64. Leamon CP, Parker MA, Vlahov IR, Xu LC, Reddy JA, Vetzel M and Douglas N. Synthesis and biological evaluation of EC20: a new folate-derived, (99m)Tc-based radiopharmaceutical. Bioconjug Chem. 2002; 13:12001210.

65. Konda SD, Aref $\mathrm{M}$, Brechbiel $\mathrm{M}$ and Wiener EC. Development of a tumor-targeting MR contrast agent using the high-affinity folate receptor: work in progress. Invest Radiol. 2000; 35:50-57.

66. Meier R, Henning TD, Boddington S, Tavri S, Arora S, Piontek G, Rudelius M, Corot C and Daldrup-Link HE. Breast cancers: MR imaging of folate-receptor expression with the folate-specific nanoparticle P1133. Radiology. 2010; 255:527-535.

67. Maurer AH, Elsinga P, Fanti S, Nguyen B, Oyen WJ and Weber WA. Imaging the folate receptor on cancer cells with 99mTc-etarfolatide: properties, clinical use, and future potential of folate receptor imaging. J Nucl Med. 2014; 55:701-704.

68. Yamada Y, Nakatani H, Yanaihara H and Omote M. Phase I clinical trial of $99 \mathrm{mTc}$-etarfolatide, an imaging agent for folate receptor in healthy Japanese adults. Ann Nucl Med. 2015; 29:792-798.

69. Reddy JA, Westrick E, Santhapuram HK, Howard SJ, Miller ML, Vetzel M, Vlahov I, Chari RV, Goldmacher VS and Leamon CP. Folate receptor-specific antitumor activity of EC131, a folate-maytansinoid conjugate. Cancer Res. $2007 ; 67: 6376-6382$
70. ClinicalTrials.gov. US National Library of Medicine, US National Institutes of Health, Bethesda (MD). Available from: https://clinicaltrials.gov/.

71. Vlahov IR, Santhapuram HK, Kleindl PJ, Howard SJ, Stanford KM and Leamon CP. Design and regioselective synthesis of a new generation of targeted chemotherapeutics. Part 1: EC145, a folic acid conjugate of desacetylvinblastine monohydrazide. Bioorg Med Chem Lett. 2006; 16:5093-5096.

72. Dosio F, Milla P and Cattel L. EC-145, a folate-targeted Vinca alkaloid conjugate for the potential treatment of folate receptor-expressing cancers. Curr Opin Investig Drugs. 2010; 11:1424-1433.

73. Pribble P and Edelman MJ. EC145: a novel targeted agent for adenocarcinoma of the lung. Expert Opin Investig Drugs. 2012; 21:755-761.

74. Lorusso PM, Edelman MJ, Bever SL, Forman KM, Pilat M, Quinn MF, Li J, Heath EI, Malburg LM, Klein PJ, Leamon CP, Messmann RA and Sausville EA. Phase I study of folate conjugate EC145 (Vintafolide) in patients with refractory solid tumors. J Clin Oncol. 2012; 30:4011-4016.

75. Edelman MJ, Harb WA, Pal SE, Boccia RV, Kraut MJ, Bonomi P, Conley BA, Rogers JS, Messmann RA and Garon EB. Multicenter trial of EC145 in advanced, folatereceptor positive adenocarcinoma of the lung. $\mathrm{J}$ Thorac Oncol. 2012; 7:1618-1621.

76. Hanna N, Juhász E, Cainap C, Gladkov O, Ramlau R, JuanVidal O, Lal R, Symanowski J, Perez W, Nguyen B and Harb W. Target: A randomized, phase II trial comparing vintafolide versus vintafolide plus docetaxel, versus docetaxel alone in second line treatment of folate-receptorpositive non-small cell lung cancer (NSCLC) patients. Annals of Oncology. 2014; 25:v1-v41.

77. Naumann RW, Coleman RL, Burger RA, Sausville EA, Kutarska E, Ghamande SA, Gabrail NY, Depasquale SE, Nowara E, Gilbert L, Gersh RH, Teneriello MG, Harb WA, Konstantinopoulos PA, Penson RT, Symanowski JT, et al. PRECEDENT: a randomized phase II trial comparing vintafolide (EC145) and pegylated liposomal doxorubicin (PLD) in combination versus PLD alone in patients with platinum-resistant ovarian cancer. J Clin Oncol. 2013; 31:4400-4406.

78. Merck Press Release. Merck and endocyte announce independent dsmb recommends vintafolide proceed phase 3 trial be stopped for futility following interim analysis 2014; Available from: http://investor.endocyte.com/releasedetail. cfm? ReleaseID $=844838$.

79. Sharma S, Sausville EA, LoRusso P, Vogelzang NJ, Samlowski WE, Carter J, Forman K, Bever S and Messmann RA. A phase I study of EC0225 administered weeks 1 and 2 of a 4-week cycle. J Clin Oncol. 2010; 28:3082.

80. Gokhale M, Thakur A and Rinaldi F. Degradation of BMS753493, a novel epothilone folate conjugate anticancer agent. Drug Dev Ind Pharm. 2013; 39:1315-1327. 
81. Peethambaram PP, Hartmann LC, Jonker DJ, de Jonge M, Plummer ER, Martin L, Konner J, Marshall J, Goss GD, Teslenko V, Clemens PL, Cohen LJ, Ahlers CM and Alland L. A phase I pharmacokinetic and safety analysis of epothilone folate (BMS-753493), a folate receptor targeted chemotherapeutic agent in humans with advanced solid tumors. Invest New Drugs. 2015; 33:321-331.

82. Leamon CP, Reddy JA, Klein PJ, Vlahov IR, Dorton R, Bloomfield A, Nelson M, Westrick E, Parker N, Bruna K, Vetzel M, Gehrke M, Nicoson JS, Messmann RA, LoRusso PM and Sausville EA. Reducing undesirable hepatic clearance of a tumor-targeted vinca alkaloid via novel saccharopeptidic modifications. J Pharmacol Exp Ther. 2011; 336:336-343.

83. Aronov O, Horowitz AT, Gabizon A and Gibson D. Folatetargeted PEG as a potential carrier for carboplatin analogs. Synthesis and in vitro studies. Bioconjug Chem. 2003; 14:563-574.

84. Lee JW, Lu JY, Low PS and Fuchs PL. Synthesis and evaluation of taxol-folic acid conjugates as targeted antineoplastics. Bioorg Med Chem. 2002; 10:2397-2414.

85. Reddy JA, Dorton R, Dawson A, Vetzel M, Parker N, Nicoson JS, Westrick E, Klein PJ, Wang Y, Vlahov IR and Leamon CP. In vivo structural activity and optimization studies of folate-tubulysin conjugates. Mol Pharm. 2009; 6:1518-1525.

86. Kurahara H, Takao S, Kuwahata T, Nagai T, Ding Q, Maeda K, Shinchi H, Mataki Y, Maemura K, Matsuyama T and Natsugoe S. Clinical significance of folate receptor betaexpressing tumor-associated macrophages in pancreatic cancer. Ann Surg Oncol. 2012; 19:2264-2271.

87. Nagai T, Tanaka M, Tsuneyoshi Y, Xu B, Michie SA, Hasui K, Hirano H, Arita K and Matsuyama T. Targeting tumorassociated macrophages in an experimental glioma model with a recombinant immunotoxin to folate receptor beta. Cancer Immunol Immunother. 2009; 58:1577-1586.

88. Tang X, Mo C, Wang Y, Wei D and Xiao H. Anti-tumour strategies aiming to target tumour-associated macrophages. Immunology. 2013; 138:93-104.

89. Xia W, Hilgenbrink AR, Matteson EL, Lockwood MB, Cheng JX and Low PS. A functional folate receptor is induced during macrophage activation and can be used to target drugs to activated macrophages. Blood. 2009; 113:438-446.

90. Fisher RE, Siegel BA, Edell SL, Oyesiku NM, Morgenstern DE, Messmann RA and Amato RJ. Exploratory study of 99mTc-EC20 imaging for identifying patients with folate receptor-positive solid tumors. J Nucl Med. 2008; 49:899906.

91. Jackman AL, Theti DS and Gibbs DD. Antifolates targeted specifically to the folate receptor. Adv Drug Deliv Rev. 2004; 56:1111-1125.

92. Wang L, Wallace A, Raghavan S, Deis SM, Wilson MR, Yang S, Polin L, White K, Kushner J, Orr S, George C,
O'Connor C, Hou Z, Mitchell-Ryan S, Dann CE, 3rd, Matherly LH, et al. 6-Substituted Pyrrolo [2,3-d]pyrimidine Thienoyl Regioisomers as Targeted Antifolates for Folate Receptor alpha and the Proton-Coupled Folate Transporter in Human Tumors. J Med Chem. 2015; 58:6938-6959.

93. Theti DS, Bavetsias V, Skelton LA, Titley J, Gibbs D, Jansen G and Jackman AL. Selective delivery of CB300638, a cyclopenta [g]quinazoline-based thymidylate synthase inhibitor into human tumor cell lines overexpressing the alpha-isoform of the folate receptor. Cancer Res. 2003; 63:3612-3618.

94. Gibbs DD, Theti DS, Wood N, Green M, Raynaud F, Valenti M, Forster MD, Mitchell F, Bavetsias V, Henderson E and Jackman AL. BGC 945, a novel tumorselective thymidylate synthase inhibitor targeted to alphafolate receptor-overexpressing tumors. Cancer Res. 2005; 65:11721-11728.

95. Pillai RG, Forster M, Perumal M, Mitchell F, Leyton J, Aibgirhio FI, Golovko O, Jackman AL and Aboagye EO. Imaging pharmacodynamics of the alpha-folate receptortargeted thymidylate synthase inhibitor BGC 945. Cancer Res. 2008; 68:3827-3834.

96. Hernando JJ, Park TW, Fischer HP, Zivanovic O, Braun M, Polcher M, Grunn U, Leutner C, Potzsch B and Kuhn W. Vaccination with dendritic cells transfected with mRNAencoded folate-receptor-alpha for relapsed metastatic ovarian cancer. Lancet Oncol. 2007; 8:451-454.

97. Amato RJ, Shetty A, Lu Y, Ellis R and Low PS. A phase I study of folate immune therapy (EC90 vaccine administered with GPI-0100 adjuvant followed by EC17) in patients with renal cell carcinoma. J Immunother. 2013; 36:268-275.

98. Li S, Tong J, Rahman MM, Shepherd TG and McFadden G. Oncolytic virotherapy for ovarian cancer. Oncolytic Virother. 2012; 1:1-21.

99. Hasegawa K, Nakamura T, Harvey M, Ikeda Y, Oberg A, Figini M, Canevari S, Hartmann LC and Peng KW. The use of a tropism-modified measles virus in folate receptortargeted virotherapy of ovarian cancer. Clin Cancer Res. 2006; 12:6170-6178.

100. Ebel W, Routhier EL, Foley B, Jacob S, McDonough JM, Patel RK, Turchin HA, Chao Q, Kline JB, Old LJ, Phillips MD, Nicolaides NC, Sass PM and Grasso L. Preclinical evaluation of MORAb-003, a humanized monoclonal antibody antagonizing folate receptor-alpha. Cancer Immun. 2007; 7:6.

101. Kamen BA and Smith AK. Farletuzumab, an anti-folate receptor alpha antibody, does not block binding of folate or anti-folates to receptor nor does it alter the potency of anti-folates in vitro. Cancer Chemother Pharmacol. 2012; 70:113-120.

102. Thomas A, Maltzman J and Hassan R. Farletuzumab in lung cancer. Lung Cancer. 2013; 80:15-18.

103. Lin J, Spidel JL, Maddage CJ, Rybinski KA, Kennedy RP, Krauthauser CL, Park YC, Albone EF, Jacob S, Goserud 
MT, Martinez BP, Chao Q, Zhou Y, Nicolaides NC, Kline JB and Grasso L. The antitumor activity of the human FOLR1-specific monoclonal antibody, farletuzumab, in an ovarian cancer mouse model is mediated by antibodydependent cellular cytotoxicity. Cancer Biol Ther. 2013; 14:1032-1038.

104. Wen Y, Graybill WS, Previs RA, Hu W, Ivan C, Mangala LS, Zand B, Nick AM, Jennings NB, Dalton HJ, Sehgal V, Ram P, Lee JS, Vivas-Mejia PE, Coleman RL and Sood AK. Immunotherapy targeting folate receptor induces cell death associated with autophagy in ovarian cancer. Clin Cancer Res. 2015; 21:448-459.

105. Konner JA, Bell-McGuinn KM, Sabbatini P, Hensley ML, Tew WP, Pandit-Taskar N, Vander Els N, Phillips MD, Schweizer C, Weil SC, Larson SM and Old LJ. Farletuzumab, a humanized monoclonal antibody against folate receptor alpha, in epithelial ovarian cancer: a phase I study. Clin Cancer Res. 2010; 16:5288-5295.

106. Kim KH, Jelovac D, Armstrong DK, Schwartz B, Weil SC, Schweizer C and Alvarez RD. Phase 1b safety study of farletuzumab, carboplatin and pegylated liposomal doxorubicin in patients with platinum-sensitive epithelial ovarian cancer. Gynecol Oncol. 2016; 140:210-214.

107. Armstrong DK, White AJ, Weil SC, Phillips $M$ and Coleman RL. Farletuzumab (a monoclonal antibody against folate receptor alpha) in relapsed platinum-sensitive ovarian cancer. Gynecol Oncol. 2013; 129:452-458.

108. Marchetti C, Palaia I, Giorgini M, De Medici C, Iadarola R, Vertechy L, Domenici L, Di Donato V, Tomao F, Muzii $\mathrm{L}$ and Benedetti Panici P. Targeted drug delivery via folate receptors in recurrent ovarian cancer: a review. Onco Targets Ther. 2014; 7:1223-1236.

109. Morphotek ${ }^{\circledR}$, Inc. Morphotek announces collaboration with mayo clinic to apply its folate receptor alpha diagnostic assays in a phase ii clinical trial in triple-negative breast cancer. 2016; Available from: http://www.morphotek. com/news-events/News-Archive/2016-News/MorphotekAnnounces-Collaboration-with-Mayo-Clinic.aspx.

110. Coney LR, Mezzanzanica D, Sanborn D, Casalini P, Colnaghi MI and Zurawski VR, Jr. Chimeric murinehuman antibodies directed against folate binding receptor are efficient mediators of ovarian carcinoma cell killing. Cancer Res. 1994; 54:2448-2455.

111. Crippa F, Bolis G, Seregni E, Gavoni N, Scarfone G, Ferraris C, Buraggi GL and Bombardieri E. Single-dose intraperitoneal radioimmunotherapy with the murine monoclonal antibody I-131 MOv18: clinical results in patients with minimal residual disease of ovarian cancer. Eur J Cancer. 1995; 31A:686-690.

112. Molthoff CF, Prinssen HM, Kenemans P, van Hof AC, den Hollander W and Verheijen RH. Escalating protein doses of chimeric monoclonal antibody MOv18 immunoglobulin $\mathrm{G}$ in ovarian carcinoma patients: a phase I study. Cancer. $1997 ; 80: 2712-2720$

113. Buijs WC, Tibben JG, Boerman OC, Molthoff CF,
Massuger LF, Koenders EB, Schijf CP, Siegel JA and Corstens FH. Dosimetric analysis of chimeric monoclonal antibody cMOv18 IgG in ovarian carcinoma patients after intraperitoneal and intravenous administration. Eur J Nucl Med. 1998; 25:1552-1561.

114. Casalini P, Mezzanzanica D, Canevari S, Della Torre G, Miotti S, Colnaghi MI and Matzku S. Use of combination of monoclonal antibodies directed against three distinct epitopes of a tumor-associated antigen: analysis of cell binding and internalization. Int J Cancer. 1991; 48:284-290.

115. van Zanten-Przybysz I, Molthoff C, Gebbinck JK, von Mensdorff-Pouilly S, Verstraeten R, Kenemans P and Verheijen R. Cellular and humoral responses after multiple injections of unconjugated chimeric monoclonal antibody MOv18 in ovarian cancer patients: a pilot study. J Cancer Res Clin Oncol. 2002; 128:484-492.

116. Macor P, Mezzanzanica D, Cossetti C, Alberti P, Figini M, Canevari S and Tedesco F. Complement activated by chimeric anti-folate receptor antibodies is an efficient effector system to control ovarian carcinoma. Cancer Res. 2006; 66:3876-3883.

117. Figini M, Obici L, Mezzanzanica D, Griffiths A, Colnaghi MI, Winter G and Canevari S. Panning phage antibody libraries on cells: isolation of human Fab fragments against ovarian carcinoma using guided selection. Cancer Res. 1998; 58:991-996.

118. Schutsky K, Song DG, Lynn R, Smith JB, Poussin M, Figini M, Zhao Y and Powell DJ Jr. Rigorous optimization and validation of potent RNA CAR T cell therapy for the treatment of common epithelial cancers expressing folate receptor. Oncotarget. 2015; 6:28911-28928. doi: 10.18632/ oncotarget.5029.

119. Figini M, Marks JD, Winter G and Griffiths AD. In vitro assembly of repertoires of antibody chains on the surface of phage by renaturation. J Mol Biol. 1994; 239:68-78.

120. Figini M, Martin F, Ferri R, Luison E, Ripamonti E, Zacchetti A, Mortarino M, Di Cioccio V, Maurizi G, Allegretti $\mathrm{M}$ and Canevari S. Conversion of murine antibodies to human antibodies and their optimization for ovarian cancer therapy targeted to the folate receptor. Cancer Immunol Immunother. 2009; 58:531-546.

121. Zacchetti A, Martin F, Luison E, Coliva A, Bombardieri E, Allegretti M, Figini M and Canevari S. Antitumor effects of a human dimeric antibody fragment 131I-AFRA-DFM5.3 in a mouse model for ovarian cancer. J Nucl Med. 2011; 52:1938-1946.

122. Gould HJ, Mackay GA, Karagiannis SN, O’Toole CM, Marsh PJ, Daniel BE, Coney LR, Zurawski VR, Jr., Joseph M, Capron M, Gilbert M, Murphy GF and Korngold R. Comparison of IgE and IgG antibody-dependent cytotoxicity in vitro and in a SCID mouse xenograft model of ovarian carcinoma. Eur J Immunol. 1999; 29:3527-3537.

123. Karagiannis SN, Josephs DH, Karagiannis P, Gilbert AE, Saul L, Rudman SM, Dodev T, Koers A, Blower PJ, Corrigan C, Beavil AJ, Spicer JF, Nestle FO and Gould HJ. 
Recombinant IgE antibodies for passive immunotherapy of solid tumours: from concept towards clinical application. Cancer Immunol Immunother. 2012; 61:1547-1564.

124. Karagiannis SN, Bracher MG, Beavil RL, Beavil AJ, Hunt J, McCloskey N, Thompson RG, East N, Burke F, Sutton BJ, Dombrowicz D, Balkwill FR and Gould HJ. Role of $\mathrm{IgE}$ receptors in $\mathrm{IgE}$ antibody-dependent cytotoxicity and phagocytosis of ovarian tumor cells by human monocytic cells. Cancer Immunol Immunother. 2008; 57:247-263.

125. Karagiannis SN, Bracher MG, Hunt J, McCloskey N, Beavil RL, Beavil AJ, Fear DJ, Thompson RG, East N, Burke F, Moore RJ, Dombrowicz DD, Balkwill FR and Gould HJ. IgE-antibody-dependent immunotherapy of solid tumors: cytotoxic and phagocytic mechanisms of eradication of ovarian cancer cells. J Immunol. 2007; 179:2832-2843.

126. Karagiannis SN, Wang Q, East N, Burke F, Riffard S, Bracher MG, Thompson RG, Durham SR, Schwartz LB, Balkwill FR and Gould HJ. Activity of human monocytes in IgE antibody-dependent surveillance and killing of ovarian tumor cells. Eur J Immunol. 2003; 33:1030-1040.

127. Bracher M, Gould HJ, Sutton BJ, Dombrowicz D and Karagiannis SN. Three-colour flow cytometric method to measure antibody-dependent tumour cell killing by cytotoxicity and phagocytosis. J Immunol Methods. 2007; 323:160-171.

128. Saul L, Josephs DH, Cutler K, Bradwell A, Karagiannis P, Selkirk C, Gould HJ, Jones P, Spicer JF and Karagiannis $\mathrm{SN}$. Comparative reactivity of human IgE to cynomolgus monkey and human effector cells and effects on $\operatorname{IgE}$ effector cell potency. MAbs. 2014; 6:509-522.

129. Rudman SM, Josephs DH, Cambrook H, Karagiannis P, Gilbert AE, Dodev T, Hunt J, Koers A, Montes A, Taams L, Canevari S, Figini M, Blower PJ, Beavil AJ, Nicodemus $\mathrm{CF}$, Corrigan $\mathrm{C}$, et al. Harnessing engineered antibodies of the IgE class to combat malignancy: initial assessment of FcvarepsilonRI-mediated basophil activation by a tumour-specific IgE antibody to evaluate the risk of type I hypersensitivity. Clin Exp Allergy. 2011; 41:1400-1413.

130. Josephs DH, Spicer JF, Karagiannis P, Gould HJ and Karagiannis SN. IgE immunotherapy: a novel concept with promise for the treatment of cancer. MAbs. 2014; 6:54-72.
131. Josephs DH, Bax HJ and Karagiannis SN. Tumourassociated macrophage polarisation and re-education with immunotherapy. Front Biosci (Elite Ed). 2015; 7:293-308.

132. Canevari S, Stoter G, Arienti F, Bolis G, Colnaghi MI, Di Re EM, Eggermont AM, Goey SH, Gratama JW, Lamers $\mathrm{CH}$ and et al. Regression of advanced ovarian carcinoma by intraperitoneal treatment with autologous $\mathrm{T}$ lymphocytes retargeted by a bispecific monoclonal antibody. J Natl Cancer Inst. 1995; 87:1463-1469.

133. Kershaw MH, Westwood JA, Parker LL, Wang G, Eshhar Z, Mavroukakis SA, White DE, Wunderlich JR, Canevari S, Rogers-Freezer L, Chen CC, Yang JC, Rosenberg SA and Hwu P. A phase I study on adoptive immunotherapy using gene-modified $\mathrm{T}$ cells for ovarian cancer. Clin Cancer Res. 2006; 12:6106-6115.

134. Miotti S, Negri DR, Valota O, Calabrese M, Bolhuis RL, Gratama JW, Colnaghi MI and Canevari S. Level of anti-mouse-antibody response induced by bi-specific monoclonal antibody OC/TR in ovarian-carcinoma patients is associated with longer survival. Int J Cancer. 1999; 84:62-68.

135. Song DG, Ye Q, Carpenito C, Poussin M, Wang LP, Ji C, Figini M, June $\mathrm{CH}$, Coukos $\mathrm{G}$ and Powell DJ, Jr. In vivo persistence, tumor localization, and antitumor activity of CAR-engineered T cells is enhanced by costimulatory signaling through CD137 (4-1BB). Cancer Res. 2011; 71:4617-4627.

136. Ribas A. Releasing the Brakes on Cancer Immunotherapy. N Engl J Med. 2015; 373:1490-1492.

137. Hamanishi J, Mandai M and Konishi I. Immune checkpoint inhibition in ovarian cancer. Int Immunol. 2016.

138. Marrone KA and Brahmer JR. Immune Checkpoint Therapy in Non-Small Cell Lung Cancer. Cancer J. 2016; 22:81-91.

139. Pusztai L, Karn T, Safonov A, Abu-Khalaf MM and Bianchini G. New Strategies in Breast Cancer: Immunotherapy. Clin Cancer Res. 2016; 22:2105-2110.

140. Ring KL, Pakish J and Jazaeri AA. Immune Checkpoint Inhibitors in the Treatment of Gynecologic Malignancies. Cancer J. 2016; 22:101-107. 